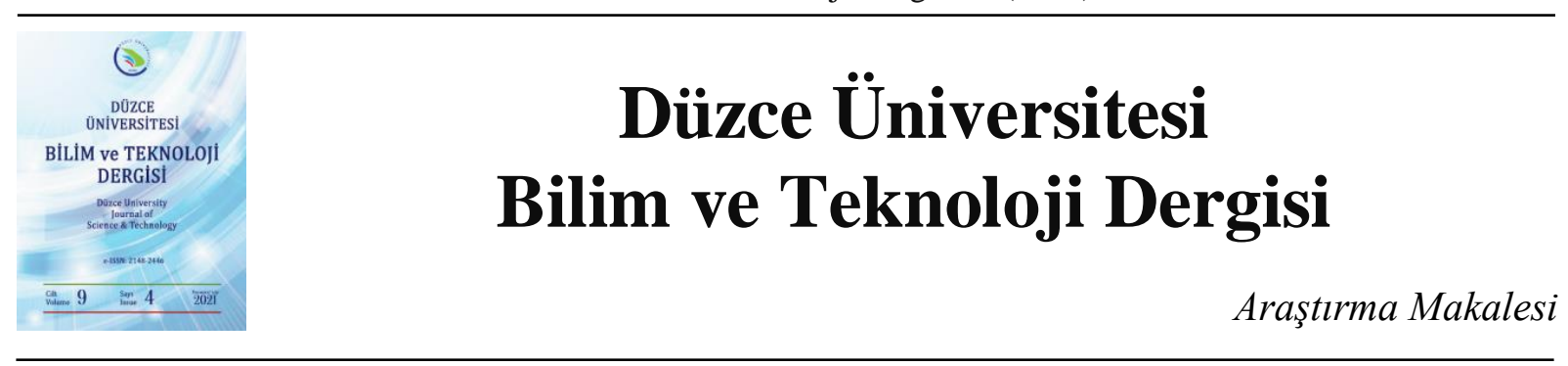

\title{
Metal Sektöründe İş Kazaları ve İşçiler Üzerindeki Etkileri: Magnezyum Metal Üretim Tesisi Örnek Çalışması
}

\author{
Abdul Vahap KORKMAZ ${ }^{\text {a, }}$ \\ a İnşaat Bölümü, İscehisar MYO, Afyon Kocatepe Üniversitesi, Afyonkarahisar, TÜRKIYYE \\ * Sorumlu yazarin e-posta adresi: avkorkmaz@aku.edu.tr
}

DOI: DOI: 10.29130/dubited.735819

\begin{abstract}
ÖZ
$\mathrm{Bu}$ çalışmanın amacı, magnezyum üretim proseslerinde, iş sağlığı ve güvenliği risk yönetimine göre Fine Kinney tipi risk analiz yöntemi kullanılarak endüstriyel ölçekte güvenlik risk derecelerini belirlemektir. 2019 yllından itibaren Türkiye'de ve Avrupa'da tek ve birincil magnezyum üretim tesisi olarak faaliyetlerine devam eden işletmede dolomit madeninden Pigdeon metoduyla yılda 15.000 ton magnezyum külçe ve magnezyum alaşımları üretilmektedir. Hafif ve mukavemetli olması nedeniyle ağırlıklı olarak elektronik, uçak, savunma ve otomotiv sanayinde kullanılan magnezyum, günümüz teknolojisi için başta Avrupa olmak üzere Dünya'nın birçok yerinde stratejik ürün olarak kabul edilmektedir. Türkiye'de kurulan Magnezyum Tesisinin tasarım aşamasında dünyadaki en iyi örnekler incelenmiş, farklı teknoloji ve yöntemlerin en güçlü yönleri birleştirilerek hibrit bir teknoloji yaratılmıştır. İş sağlığı ve güvenliğinin üst düzeyde var olabilmesi için dünyadaki örneklerinden farklı olarak mekanizasyon yatırımları yapılmış ve çok daha güvenli bir çalışma ortamı yaratılmıştır. Fakat sektörün ülkemizde yeni, ilk ve tek olması beraberinde tecrübesizlik, acemilik ve iş güvenliği risklerini de beraberinde getirmiștir. $\mathrm{Bu}$ amaçla Magnezyum Fabrikasında riskleri tanımlamak, tehlikeleri en aza indirmek ve riskleri derecelendirmek için İşveren vekili, iş güvenliği uzmanı, işyeri hekimi, çalışan temsilcisi, destek elemanları ve iş yeri dışından hizmet alımı yoluyla ortak sağlık güvenlik birimi iş güvenliği uzmanları katılımıyla Fine Kinney metodolojisi kullanılarak risk değerlendirme çalışmaları yapılmıştır. Çalışma işyeri ziyareti, dolomit ocak işletmesi, hammadde hazırlama, depolama ve nakliye, dolomit öğütme, kalsinasyon, peletleme, redüksiyon, rafinasyon, ünitelerini kapsamaktadır. Magnezyum üretim tesisinde öncelikle olası tüm riskler tanımlanarak sıralanmış, risklerin olasılığı ve şiddeti belirlenmiş ve mevcut değerler kullanılarak risk dereceleri hesaplanmıştır. Risklerin belirlenmesinden sonra güvenlik riski tabloları hazırlanmış ve olası riskler iş güvenliği risk yönetimi sistemi açısından yüksek, orta ve düşük risk derecelerine göre sınıflandırılmıştır. Risk değerlendirmesi sonuçlarına göre en tehlikeli risk bölgesi olarak redüksiyon ve rafinasyon üniteleri belirlenmiştir. Öte yandan, en yüksek risk puanı da hammadde öğütme bölümünde elde edilmiştir. Ocaklar, kırıc1, öğütme ve peletlemenin en yoğun toz, gürültü ve titreşim üreten üniteler olduğu sonucuna varılmış̧ır.
\end{abstract}

Anahtar Kelimeler: Magnezyum, Metal, Tehlike, Fine Kinney, İ̧ güvenliği, Risk

\section{Occupational Accidents in Metal Industry and Their Effects on Workers: Magnesium Metal Production Plant Case Study}

\begin{abstract}
$\underline{\text { ABSTRACT }}$
The purpose of this study is to determine the safety risk levels on an industrial scale by using Fine Kinney type risk analysis method in magnesium production processes according to occupational health and safety risk management. Since 2019 in Turkey and in Europe as the sole and primary magnesium production plant Pigdeo
\end{abstract}


method from dolomite mine continued to operate the business year 15,000 tons of magnesium ingots and magnesium alloys are produced. Magnesium, which is mainly used in electronics, aircraft, defense and automotive industries due to its lightness and strength, is considered as a strategic product in many parts of the world, especially in Europe, for today's technology. Established in Turkey were examined at the design stage of the world's best examples Magnesium Plant, has created a hybrid technology combining the strengths of different technologies and methods. In order for occupational health and safety to exist at a high level, mechanization investments have been made, unlike the examples in the world, and a much safer working environment has been created. However, the fact that the sector is new, first and only in our country has brought along inexperience, inexperience and occupational safety risks. For this purpose, field studies using the Fine Kinney methodology with the participation of employer representative, occupational safety specialist, workplace doctor, employee representative, support staff and out-of-work service procurement from the joint health and safety unit occupational safety experts in order to identify risks, reduce hazards and rate risks in the Magnesium Factory. has been made. The study includes workplace visit, dolomite quarry operation, raw material preparation, storage and transportation, dolomite grinding, calcination, pelletizing, reduction, refining units. At the magnesium production facility, firstly, all possible risks were identified and listed, the probability and severity of the risks were determined and the risk levels were calculated using the existing values. After the identification of the risks, security risk tables were prepared and possible risks were classified according to high, medium and low risk levels in terms of occupational safety risk management system. According to the results of the risk assessment, reduction and refining units were determined as the most dangerous risk area. On the other hand, the highest risk score was obtained in the raw material grinding section. It has been observed that the crusher, raw material, cement grinding and rotary kiln are the most dust, noise and vibration generating units.

Keywords: Magnesium, Metal, Hazard, Fine Kinney, Occupational safety, Risk,

\section{GIRIS}

Günümüz teknolojisindeki yeniliklerle mücadelede risk değerlendirmesi büyük önem taşımaktadır. Magnezyum metal sektörü, üretim süreçlerindeki yeniliklerden kaynaklanan yüksek risk faktörlerini sürekli olarak dikkate alması gereken bir endüstri koludur. Özellikle ülkemizin magnezyum metal madenciliği konusunda yeni yeni bilgi ve deneyime sahip olduğunu ve Avrupa'nın bu konuda hiçbir bilgi ve tecrübeye sahip olmadığı göz ardı edilmemelidir [1].

Dünyadaki magnezyum metal üretiminin \%85'i Çin, Avrupa' da ise magnezyum metal üretimi Türkiye dışındaki herhangi bir ülkede üretilmeyip Çin ya da Amerika' dan satın alma yoluyla temin edilmektedir. Bu nedenle 2011 yllında Avrupa, magnezyum metalini kritik hammaddeler listesine dahil etmiştir [1]. Türkiye'de 2017 yılında ilk entegre magnezyum üretiminin başlatılması da ülkemiz ve Avrupa için stratejik öneme sahiptir. Fabrikadaki magnezyum üretimi \%99,80-99,95 saflıkta ve her bir külçe magnezyum 8-12 kg ağırlığındadır [1].

Türkiye birincil magnezyum tesisi üretim yöntemi olarak Çin'de yaygın olarak kullanılan Pidgeon prosesini (silikotermik indirgenme) tercih etmiştir. Türkiye'deki magnezyum üretim tesisinde kullanılan proses makineleri ve cihazları Çin'deki tesislerden faklı olarak (maden hazırlama, kalsinasyon, redüksiyon, metalürji tesisleri) birçok yenilik ve iyileştirmeler içermektedir [2]. Hem kurulum hem de proses bazındaki yenilikler, magnezyum tesisine yabancı olan Türk çalışanlar için yeni güvenlik risklerini de beraberinde getirmiştir. Türkiye'deki magnezyum tesisinin kurulum ve ilk devreye alınması aşamalarında Çinli ve Türk işçiler, Çinli işçilerin proses ve iş güvenliği deneyimlerinden faydalanmak amacı ile birlikte çalışmışlardır. Fakat Çinli işçilerin iş güvenliği kültüründen uzak olmaları ve güvenlik disiplinini çalışma hayatlarında yeterince uygulamadıkları için, Türk işçilerin sektörel bazda iş güvenliği konusundaki gelişimleri yaşa, gör ve tecrübe et yaklaşımını geliştirmelerini ve uygulamalarını sağlamıştır.

En son teknoloji ürünü tesislerde bile, çalışanlar yüksek firınlarda, haddeleme hatlarında ve dökümhanelerde tehlikeli maddelerle günlük temasa girebilirler. Magnezyum metal üretimi ve işleyişi gün boyunca kesintisiz olarak devam etmek zorundadır. Herhangi bir kesinti veya durma ciddi bir 
ekonomik kayba sebep olmaktadır. Bazı üretim aşamaları, doğrudan yüksek firında veya konvertörde nokta kontrolleri gibi makine tabanlı süreçlerle değiştirilememektedir. Bu süreçlerde yer alan kişiler, yılların tecrübesi ve eğitimi sonunda, gerekli iş güvenliği eğitimlerini almış, tehlikeler ve riskler hakkında bilgili ve olası oluşabilecek riskler konusunda öngörülü ve çalışmalarında özel uzmanlık kazanmış kişilerden oluşmaktadır. Buna rağmen tamamı önlenemeyen zehirli ve patlayıcı gazlar ve buharlar, toz parçacıkları ve 1sı nedeniyle ortaya çıkan birçok risk göz önüne alındığında, çalışanların her zaman optimum koruma ile çalışmaları ve ek risklerden kaçınmaları gerekmektedir. Bu çalışmada Türkiye'de ve Avrupa'da ilk kez entegre olarak magnezyum metal üretimi gerçekleştirilen tesisin risk değerlendirme çalışması gerçekleştirilmiştir. Metal sektöründe yapılan iş sağlığı ve güvenliği çalışmalarında 5x5 Matris ve Fine-Kinney yöntemi sıkça kullanılmış ve yapılan karşılaştırmalar iki yöntemden Fine-Kinney yönteminin 5x5 matris yöntemine kıyasla daha hassas sonuçlar verdiği görülmüştür [3]. Bu çalışmada Türkiye' de mevcut sanayi tesislerinin hazırlamış olduğu ve tanımladığ1 temel riskler haricinde magnezyum metal üretim proseslerine özgü riskler Fine Kinney risk analizi yöntemine göre ortaya konulmuş ve önceliklendirilmiştir. Böylelikle şuan ve gelecekte gerek Avrupa ve gerek Türkiye'de magnezyum metal üretim tesislerinde çalışan ve çalışacak işçiler için ortaya çıkabilecek tehlikeler, riskler, çözüm önerileri ve öngörüler bu çalışma ile ortaya çıkarılmış olunacaktır.

\section{A. MAGNEZYUM PROSESİ}

Türkiye'de 2019 yılından itibaren dolomit madeninden Pigdeon metoduyla magnezyum külçe ve magnezyum alaşımları üretilmektedir. Kalsine edilmiş dolomit ve manyezitin $\mathrm{Si}, \mathrm{Al}, \mathrm{CaC}_{2}$ ile termal redüksiyonunu keşfeden Pidgeon; kalsine dolomitin, FeSi ile redüksiyonunun ticari açıdan en avantajlı yöntem olduğunu göstermiş̧ir [4].

Türkiye'de ve diğer magnezyum üretimi yapan ülkelerde de genel olarak saf magnezyum metal külçe üretimi için ana hammadde olarak dolomit cevheri kullanılmaktadır. Dolomit cevheri ocaktan çıkartıldıktan sonra kırma eleme tesisinde boyutlandırılarak, $10-30 \mathrm{~mm}$ ve $30-50 \mathrm{~mm}$ boyutlarındaki malzeme, kalsine edilmek üzere önce $800-950{ }^{\circ} \mathrm{C}$ sicaklıktaki ön 1sitıc1 kuleye daha sonra döner firına beslenmektedir. Döner firında dolomit cevheri $1250-1300{ }^{\circ} \mathrm{C}$ sicaklılarda kalsine edilerek, elde edilen kalsine dolomit öğütülmek için hammadde silosuna aktarılmaktadır. Kalsine dolomite yaklaşık \%16-18 Ferro Silis (FeSi) ve \%1-2 Kalsiyum Florit $\left(\mathrm{CaF}_{2}\right)$ ilave edilerek değirmende öğütülmektedir. Öğütülen malzemenin 125 micron elek bakiyesi ortalama \%10 civarındadır. Ögütülmüş malzeme pelet ünitesine gönderilerek badem şeklinde peletler haline getirilmektedir [5].

Peletlenmiş malzeme ortalama sicaklığ $1200-1250^{\circ} \mathrm{C}$ olan redüksiyon firınlarında bulunan retort tüplerine beslenmektedir (Şekil 1). Bu besleme, redüklenme esnasında gaz fazın retort tüpü içerisinde kovanlara ilerlemesine izin verecek bir sıkılıkta olması için, gelberi kürekleri kullanılarak tamamen insan gücüyle yapılmaktadır. Yeterli miktarda pelet beslendikten sonra retort tüplerinin besleme ağızlarına, üzerinde soğutma ceketi de bulunan ürün toplama kovanları takılmaktadır. Retort tüpleri vakum ortamı altında 12 saat boyunca bekletilirken pelet içerisindeki $\mathrm{MgO}$ redüklenerek gaz fazda magnezyum haline gelmektedir. Gaz haldeki magnezyum metali retort tüpüne beslenen pelet boşluklarından kovan içine çekilerek, kovandaki soğutma ceketi vasıtasıyla katı halde toplanmaktadır. Kovan içinde elde edilen metal ürün taç magnezyum olup, yaklaşı \% $\% 5$ saflıktadır [5]. 

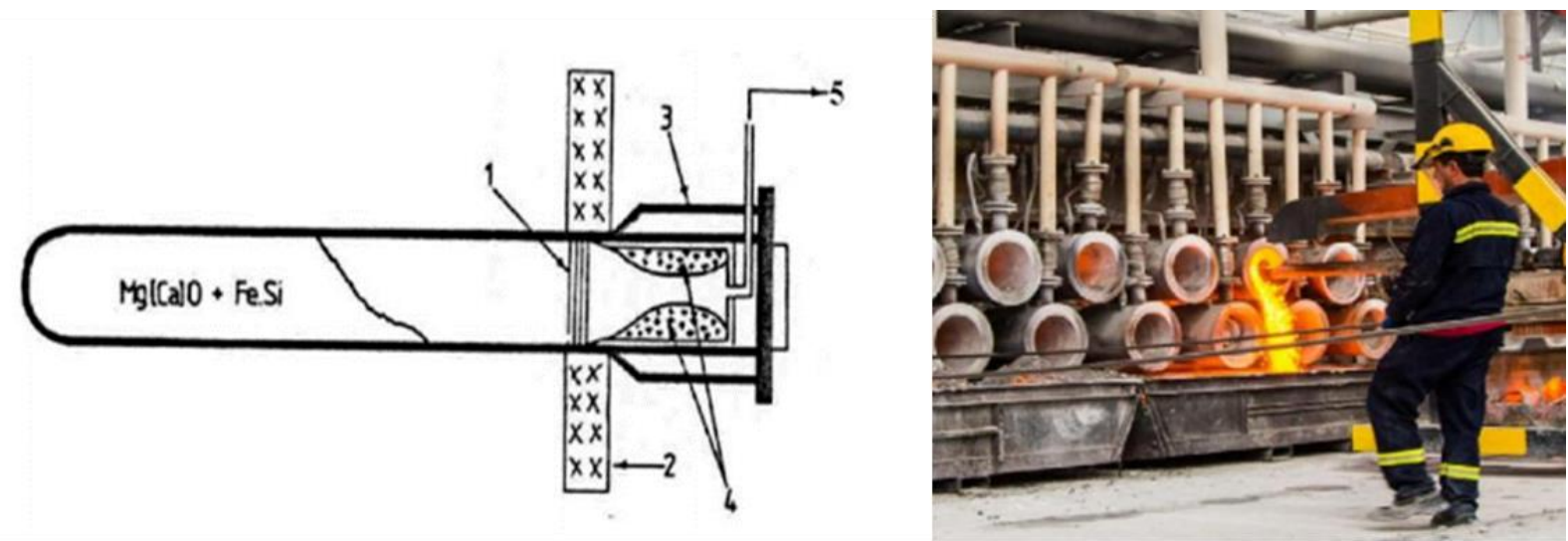

Şekil 1. Pidgeon Prosesinde kullanılan retort, 1)Radyasyon kalkanı, 2) Furın duvarı, 3)Su soğutmalı yoğunlaştırıcı, 4) Taç şekilli kristal magnezyum tanecikleri, 5) Vakum pompası bağlantısı [5].

Retort tüplerinde redükleme yoluyla elde edilen taç magnezyum kovanlardan alındıktan sonra geriye $\% 85$ civarında redüksiyon cürufu olarak adlandırılan yan ürün elde edilmektedir. Meydana gelen redüksiyon cürufu, sıcak haldeyken taşınabilir paletli bunkerlere alınarak tesisin atık depolama alanında depolanmaktadır. Bu esnada ve daha sonra redüksiyon cürufu üzerinde herhangi bir işlem yapılmamakta olup, elde edilen yan ürün atıl olarak kalmaktadır. Üretilen taç magnezyum ürünler ise saflaştırılmak üzere tesisin rafinasyon ünitesine alınmaktadır [5].

\section{METOT}

\section{A. RİSK DEĞERLENDİRMESİ VE RİSK YÖNETIMI}

Magnezyum ve diğer metal endüstrilerinde tehlikeli maruziyete karşı etkili önleme ve koruma sağlamak için, proseslerin, prosedürlerin ve tesislerin planlayıcıları ve geliştiricileri, işçiler ile temsilcileri ve yöneticiler ile İSG uzmanları arasında iş birliği ve uyum olmalıdır. Bu tür bir iş birliği, tesisteki potansiyel tehlikelerin ve risklerin tanımlanmasına ve değerlendirilmesine odaklanmalıdır. Tesiste, ortadan kaldıracak tehlikelere karşı önlemlerin alınmasını sağlamak için veya bu mümkün değilse, en azından mesleki hastalık ve yaralanma potansiyelinin düşürülmesi sağlanmalıdır. Risk değerlendirmesine dahil edilecek konularla ilgili kılavuz, madde, makine ve diğer ekipman üreticilerinden ve tedarikçilerinden temin edilmelidir. Yetkili makam ve harici uzmanlardan daha fazla rehberlik talep edilmelidir. Örneğin; mesleki hijyenistler, yetkin mühendisler ve meslek hekimliği uzmanları. Günlük çalışma uygulamaları hakkında ayrıca işverenlere tesislerinde gelişen uygulamalarda yardımcı olabilecek ve iyileştirme önerileri sunabilecek değerli bilgiler işçilerden ve temsilcilerinden temin edilebilmelidir. Sonuç olarak, tesiste meydana gelebilecek olası tehlikeler etkin bir şekilde kontrol edilse bile, işverenler ve iş̧̧ilerin risklerle ilgili kararlarından ve eylemlerinden yararlanma ve işçilerin sağlığına potansiyel katkılarının olabileceği göz ardı edilmemelidir [6].

Başarılı bir risk değerlendirmesinin temel adımları aşağıdaki gibidir:

(i) güvenlik ve sağlığa yönelik riskleri ve bunları kontrol etmek için gerekli önlemleri belirlemek ve ölçmek için süreçleri ve iş faaliyetlerini gözlemlemek.

(ii) en ciddi olandan başlayarak, gerekli risk kontrol önlemlerini öncelik sırasına göre uygulamak. Uygulama sırasında ve hemen sonrasında, tespit edilen kontrol önlemlerinin yeterli olduğundan emin olmak için alınan önlemlerin etkinliği değerlendirmek.

(iii) uygulanan risk kontrol önlemlerinin sürdürülmesine dahil olacak tüm kişilere bilgi, talimat ve eğitim olanağı ve katılımlarını sağlamak;

(iv) uygulanan risk kontrol önlemleri ve eğitim programlarının sürekli etkinliğini periyodik olarak izlemek, gözden geçirmek ve değerlendirmek ve uygunsa, gerekli iyileştirmeleri belirlemek. Özellikle, 
süreç ve personeldeki herhangi bir değişikliğin ardından ve tehlikeli durumlar olması durumunda incelemeler yapmak. İncelemede tespit edilen herhangi bir iyileştirmeyi uygulamak

(v) risk değerlendirmesi ve kontrol tedbirlerindeki herhangi bir değişikliğin kaydını tutmak [7].

Risk değerlendirmesine dahil olan kişiler şunlara sahip olmalıdır:

(i) işyerindeki tehlikeleri ve riskleri etkili bir şekilde tanımlamak ve hastalık ve yaralanma olasılığını ve ciddiyetini değerlendirebilmek için güvenlik ve sağlık ve değerlendirilen süreçler konusunda yeterli eğitim ve deneyim;

(ii) gerekli risk kontrollerinin uygulanması konusunda bir risk değerlendirmesi yürütme ve işverenlere, işçilere ve onların temsilcilerine tavsiyelerde bulunma yeteneği;

(iii) uzmanlıklarının sınırlılıkları ve ek tavsiye gerektiğinde yetkili kaynaklardan ne zaman rehberlik ve bilgi isteneceği konusunda farkındalık;

(iv) bilgi ve becerilerini sürdürmek ve güncellemek için sürekli mesleki gelişim faaliyetlerine katılma istekliliği [8].

Magnezyum fabrikasında risk değerlendirme çalışmaları işveren vekili, iş güvenliği uzmanları ile işyeri hekimleri, işyeri çalışan temsilcileri, İşyeri destek elemanları muhtemel tehlike kaynakları ile riskler konusunda bilgi sahibi çalışanlar ve ekibe destek olmak üzere işyeri dışından ortak sağlık güvenlik birimine bağlı iş güvenliği uzmanları ile ortak çalışmaları sonucu gerçekleştirilmiştir.

Ekip öncelikle ham madde ocaklarından başlayarak, ham madde hazırlama, kalsinasyon, değirmen, peletleme, redüksiyon, rafinasyon, retort ve yardımcı ünitelerde saha denetimleri yapmıș daha sonra risk kartları, ramak kala olayları, işçilerin geri bildirimleri ve isg kurul kararları doğrultusunda risk değerlendirmesi çalışmalarını gerçekleştirmişlerdir. Çalışma kapsamında tespit edilen temel risklerin dışında magnezyum tesisine ait spesifik ve önemli riskler risk değerlendirme tablosunda (tablo 3) detaylı olarak açıklanmıştır.

\section{B. RISK METODU ICÇIN TEHLIKELERIN TANIMLANMASI}

Diğer tüm metal işlerinde olduğu gibi magnezyum metal işlerinde de büyük miktarlarda malzeme, çoğu farklı endüstriyi gölgede bırakan devasa ekipmanlarla işlenir ve taşınır. Metal işleri genellikle minimal da olsa hata kabul etmeyen bir ortamdaki tehlikeleri ele almak için gelişmiş güvenlik ve sağlik programlarına sahiptir. Tehlikeleri kontrol etmek için genellikle iyi mühendislik ve bakım uygulamalarını, güvenli iş prosedürlerini, iş̧̧i eğitimini ve kişisel koruyucu ekipman (KKD) kullanımını birleştiren entegre bir yaklaşım gerektirir. Dünya'da ve Türkiye'de magnezyum metal üretim proseslerinin her aşamasında farklı derecelerde ölümcül tehlikelerle yüzleşme ihtimali vardır. Metal işlerinin doğası gereği yapılan işlemler esnasında seçilen güvenlik metotlarının uygulanması neticesinde ölümcül olmayan fakat uzuv kaybı veya sakatlıkla sonuçlanabilecek kazalar ve ağır seyredebilecek hastalıklara maruz kalma durumu çok yüksektir. [9]. Bu nedenle risk değerlendirmesi yapılırken birincil magnezyum üretim tesisinde tehlike ve yüksek öneme sahip riskler (sıcaklık, ergimiş metal sıçraması, yüksekte çalışma, ezilme, sıkışma vb.) hem güvenlik, hem de sağlık bakımından yönetmelik ve prosedürleri çerçevesinde ele alınmıştır

Magnezyum üretimi, dikkatli bir yönetime ihtiyaç duyan yapısal tehlikelere sahip süreçleri içerir. Bunlar proses emniyeti, özellikle patlama, yangın, yapısal çökme ve erimiş metaller, yakıtlar ve kimyasal kaynaklı tehlikelerdir. Bu tehlikeleri kontrol etmek için gereken önlemler genellikle karmaşıktır. Süreç güvenliği yönetiminin odağı şirket içindeki insanların korunmasıyla sınırlı olmayıp çevreyi, varlıkları ve çevreleyen topluluğu da kapsamaktadır [10]. Magnezyum üretim tesisi tehlikeye neden olabilecek sınırları belirlenmiş faaliyet veya faaliyetler dizisi aşağıda verilmiştir;

- Erimiş metal, fırından veya potadan aktarıldığında, sıcaklık $800^{\circ} \mathrm{C}$ civarında olacaktır. Bu etkinlik sırasında dökümhane ekipleri erimiş metal sıçraması riski ile karşı karşıya kalabilmektedirler. 
- İşleme, doldurma (dökme) veya taşıma sırasında kepçelerden veya iş ekipmanlarından sıcak metal dökülmeleri, sıçramaları veya püskürmeleri

- Nihai bir ürün haline getirilirken sıcak metal ile temas.

- Magnezyum rafinasyon ünitesindeki en büyük güvenlik tehlikelerinden biri nem varlığıdır. Fırın eritme potası, dökme kepçesi veya kum kalıbının kendisinde nem varsa, metalin ısısı nedeniyle nem anında buhara dönüştüğü için yüksek enerjili reaksiyonlara yani patlamalara neden olabilir. Erimiş metal veya cüruf tarafından tutulan su, geniş bir alanda sıcak metal veya malzeme firlatan patlayıcı kuvvetler oluşturabilir.

- Erimiş magnezyum metaline nemli bir alet temas ettirilmesi şiddetli patlamalara neden olabilir.

- Metal döküm işlerinde mekanik taşımacılık esastır, ancak işçileri potansiyel tehlikelere maruz bırakır. Gezer köprülü vinçler, çelik işlerinin neredeyse tüm alanlarında bulunur. Büyük işlerin çoğu, büyük ölçüde sabit raylı ekipman ve malzeme taşımak için büyük endüstriyel araçların kullanımına dayanır. Beklenmedik vinç hareketleri yaralanmalara ve ölümlere neden olabilir.

- Çalışma ortamına ek olarak yerel egzoz gazalarının da yaydığı zehirli gazlar sonucu duman oluşumu ayrıca bir sağlık riski oluşturmaktadır.

- Makine ve ekipmanlarla güvensiz çalışma ve güvensiz hareketler

- Dökümhanede çalışma esnasında kullanılan kimyasallara maruz kalma, kimyasallarla cilt teması (tahriş edici maddeler (asitler, alkaliler, çözücüler ve duyarlılaştırıcılar);

- Sıcakta çalışma sonucu su kaybı, halsizlik ve bayılma

- Aletler ağır aşınmaya maruz kalır ve yakında tehlikeye girer ve kullanımı tehlikeli olabilir. Mekanizasyon endüstrideki manuel elleçleme miktarını büyük ölçüde azaltmış olsa da, ergonomik zorlamalar hala birçok durumda ortaya çıkabilir ve işçilerin bedenlerine zarar verebilir.

- Metal bantlardaki keskin motorlar veya çapaklar, son işlem, nakliye ve hurda elleçleme işlemlerinde yer alan çalışanlar için deride yırtılma ve delinme tehlikesi oluşturabilir.

- Yabancı cisim batması sonucu göz tehlikeleri, özellikle taşlama, kaynak ve yanma işlemlerinin yapıldığı ham madde elleçleme ve külçe temizleme işlemlerinde görülebilir.

- Büyük miktarlarda gres, yağ ve yağlayıcılar kullanılır ve dökülürse, yürüme veya çalışma yüzeylerinde kolayca kayma tehlikesi oluşturabilirler [11,12].

\section{FINE KINNEY YÖNTEMI}

Fine Kinney yöntemi emniyet riski analiz arac1, belirli bir tehlike nedeniyle ortaya çıkan riski hesaplamak için matematiksel bir formül sağlayan sistematik bir metodolojidir. Fine - Kinney'in orijinal versiyonunda önerildiği gibi, geleneksel versiyonunda, olasıllk (P), maruziyet ve sonuç parametrelerinin matematiksel çarpımının bir sonucu olarak bir risk skoru (RS) hesaplanmaktadır. Hesaplanan bu risk puanları, riskleri ortadan kaldırmak veya etkilerini makul bir düzeye indirmek için düzeltici çabalar için öncelikler belirlemek için kullanılmaktadır. Bu basit ve kullanışlı yöntem, küçük ve orta ölçekli işletmeler tarafından tercih edilmekte ve uygulanmaktadır [13]. $\mathrm{Bu}$ yöntemle her risk için üç parametre belirlenmelidir:

- Tehlike (S) ile bağlantılı yaralanmanın şiddeti;

- Tehlikeye maruz kalma;

- Maruz kaldığında meydana gelebilecek tehlike olasılığı (P). Bu kavramlar, sayısal bir yöntem haline gelmesi ve sayısal bir risk tahmini yapılabilmesi için işler hale getirilmelidir.

Olasılık; Bir olayın meydana gelme olasılığı veya (matematiksel) şansı olarak açıklanmaktadır. Beklenti, 0,1'den 10'a kadar bir değer atanarak temsil edilmektedir.

P Olasilik

0,1 İmkânsıza yakın / düşünülemez

0,2 Neredeyse hayal edilemez

0,5 Olasılığ 1 çok düşük, ancak düşünülebilir

1 Olası değil, ancak uzun vadede mümkün

3 Sıradışı (ama mümkün) 
6 Mümkün

10 Beklenecek

Maruziyet faktörü; bir riskin ortaya çıabileceği süreyi göstermektedir. Ölçek 0,5 ile 10 arasında değişmektedir.

E Maruziyet

0,5 Çok nadiren (y1lda 1 defadan az)

1 Nadiren (yaklaşık yılda $1 \mathrm{kez})$

2 Bazen (yaklaşık yilda 1x)

3 Ara sira (haftalik)

6 Sik sik (günlük)

10 Sürekli (günde birkaç kez)

Önem; faktör şiddeti, bir tehlikeyle bağlantılı olası hasarı, etkileri ve sonuçları göstermektedir. Ölçek 1'den 40'a ulaşmaktadır.

S Önem

1 Hafif etki, hastalık nedeniyle yokluk olmadan yaralanma

3 Önemli, yoklukta yaralanma

7 Yokluk ile şiddetli, kalıcı yaralanma

15 Çok ağır, ölümcül bir zayiat

40 Afet, çok sayıda ölümcül kayıp

Risk endeksi; olası hasarın ciddiyetine, maruz kalma süresine ve bir riskin olasılığına belirli sayısal değerler atfedilerek bir risk endeksi oluşturmaktadır.

Parametrelerin çarpılmasının sonucu risk endeksini tanımlamaktadır. $\mathrm{R}=\mathrm{S} \times \mathrm{E}$ x $\mathrm{P}$

Risk endeksinin beş kategorisi vardır. Bu risk endeksine dayanarak uygun (teknik) önlemler belirlenebilir. Riskler olabildiğince ortadan kaldırımalı veya azaltılmalıdır (doğası gereği güvenli makine tasarımı ve yapımı).

Ortadan kaldırılamayan risklerle ilgili gerekli koruyucu önlemleri alınmalıdır. Kullanıcılar, benimsenen koruyucu önlemlerin herhangi bir eksikliğinden kaynaklanan artık riskler konusunda bilgilendirilmelidir, herhangi bir özel eğitimin gerekli olup olmadığını belirtilmeli ve kişisel koruyucu ekipman ihtiyacı sağlanmalıdır.

Sinıflandırma risk endeksi risk ve önlemler

1. $\mathrm{R}=21$ Hafif risk; kabul edilebilir

2. $21<\mathrm{R}=71$ Küçük risk; dikkat gerekli

3. $71<\mathrm{R}=201$ Orta risk; basit önlemler uygulamak

4. $201<\mathrm{R}=401$ Yüksek risk; hemen büyük önlemler uygulayın

5. $\mathrm{R}>401$ Risk çok yüksek; faaliyetleri / işlemleri durdur [14].

\section{MAGNEZYUM METAL ÜRETIM SÜRECLERINE ÖZEL ÖNLEME VE KORUMA}

\section{A. TEHLIKKELER VE SAĞLIK ETKİLERI}

Birincil magnezyum metal endüstrisinin işgücünde işyerinde yaralanmaları ve hastalıkları önlemek için özel önlemlerin seçimi ve uygulanması, temel tehlikelerin ve beklenen yaralanma ve hastalı̆̆n 
tanınmasına bağlıdır. Magnezyum metal endüstrilerindeki en yaygın yaralanma ve hastalık nedenleri aşağıda açıklanmıştır [15].

Aynı seviyede kayma, takılma ve düşme;

$>$ Korumasız makineler;

$>$ Yüksekten düşme;

$>$ Düşen nesneler;

$>$ Mineral yünlere ve liflere maruz kalma;

$>$ Sicak metal ile temas; sıcak metal sıçraması

$>$ Ateş ve patlama;

$>$ Aşırı sıcak ortam, Sicak soğuk dengesizliği

$>$ Radyasyon (iyonlaştırıcı olmayan, iyonlaştırıc1);

$>$ Gürültü ve titreşim;

$>$ Kapalı alanlarda çalışmak;

$>$ Solunabilir ortam (gazlar, buharlar, tozlar ve dumanlar);

$>$ Hareketli makineler ve yerinde taşıma;

$>$ Kimyasallarla cilt teması (tahriş edici maddeler (asitler, alkaliler),

$>$ Çözücüler ve hassaslaştırıcılar);

$>$ Kontrollü ve kontrolsüz enerjiye maruz kalma

$>$ Elektrik yanıkları ve elektrik çarpması;

$>$ Manuel kullanım ve tekrarlayan çalışma

Aşırı gürültü, önemli sosyal ve fizyolojik etkileri olan küresel bir iş sağlığı tehlikesidir. Tüm kaynaklardan gelen yüksek sese maruz kalma, yetişkinlerde başlayan işitme kaybının yaklaşık \%20' sini oluştururken, yetişkinlerdeki işitme kaybına neden olan işitme kaybının yüzde 16'sı mesleki gürültüye atfedilmektedir. Gürültüye bağl1 işitme kaybı, dünyadaki en ciddi 15. sağlık sorunu olarak kabul edilmektedir.

Gürülttüye bağlı işitme kaybı, dünyada önlenebilir en yaygın iş sağlığı durumudur. Gürültüye maruz kalan herkes potansiyel olarak risk altındadır. Gürültü seviyesi ne kadar yüksekse ve bireyler ne kadar uzun süre maruz kalırsa, bundan zarar görme riski de o kadar artmaktadır. Dünya çapında milyonlarca işçi, işitme duyularını riske atan gürültü seviyelerine maruz kalmaktadır. Aşırı gürültü, yalnızca gürültülü işlemlerle uğraşan işçiler için değil, aynı zamanda etrafindakiler için de pek çok olumsuz etkisi olan mesleki bir tehlikedir [16].

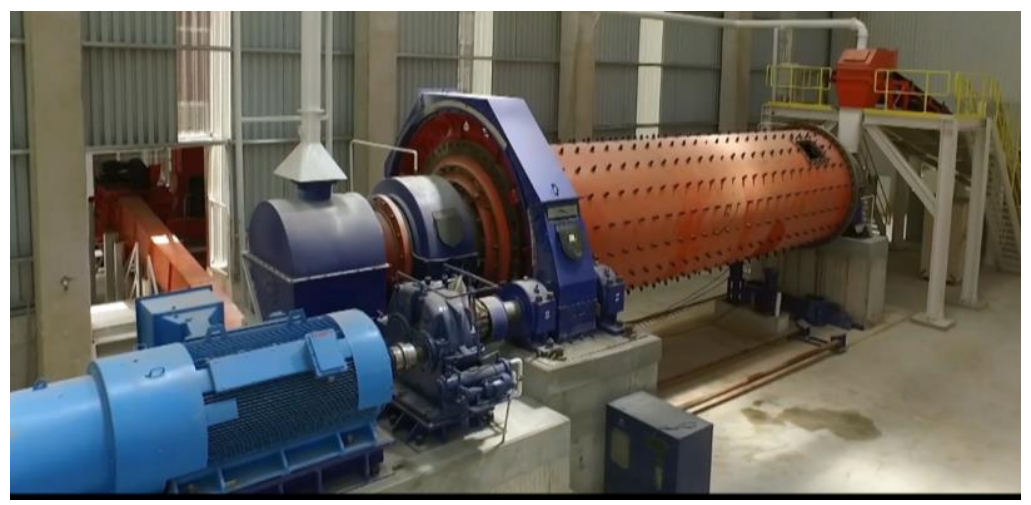

Şekil 2. Bilyalı değirmen

Magnezyum üretim tesisinde yaklaşık 20 ton üretim kapasitesine sahip bir bilyalı değirmen (Şekil 2) ile ögütme faaliyetleri gerçekleştirilmektedir. Kalsine olmuş dolomit madeni, flüorit ve ferrosilis cevheri kompozisyonu bilyalı değirmende ögütülerek 125 mikron altına inceltilmektedir. Malzemenin değirmende ögütülme işleminin çelik bilyalar marifetiyle yapılması nedeniyle ortama yüksek ses dalgaları yayılmaktadırlar. 
Tesiste yapılan bilyalı değirmen gürültü ölçüm sonucu (kişisel maruziyet) Tablo 1'de verilmiştir.

Tablo 1. Bilyalı değirmen gürültü ölçüm sonucu

\begin{tabular}{lllll} 
Çalışma Yeri & LEX dB(A) & Ppeak dB(C) & $\begin{array}{l}\text { En düşük Maruziyet } \\
\text { Eylem Değerleri } \\
{[\mathbf{d B}(\mathbf{A})-\mathbf{d B}(\mathbf{C})]}\end{array}$ & $\begin{array}{l}\text { En düşük Maruziyet } \\
\text { Eylem } \\
{[\mathbf{d B}(\mathbf{A})-\mathbf{d B}(\mathbf{C})]}\end{array}$ \\
\hline Değirmen Saha & 78,5 & 127,5 & $\mathrm{~dB}(\mathrm{~A})<80$ & $\mathrm{~dB}(\mathrm{~A})<87$ \\
$\mathrm{~dB}(\mathrm{C})]<135$ & $\mathrm{~dB}(\mathrm{C})]<140$
\end{tabular}

6331 Sayılı İş Kanununun 25325 sayılı Gürültü Yönetmeliğin uygulanması bakımından, günlük gürültü maruziyet düzeyleri ve en yüksek ses basıncı yönünden maruziyet sınır değerleri ve maruziyet etkin değerleri, aşağıda verilmiştir;

1) Maruziyet sınır değerleri: LEX, $8 \mathrm{~h}=87 \mathrm{~dB}(\mathrm{~A})$ ve ppeak $=200 \mu$ Pai 1

2) En yüksek maruziyet etkin değerleri: LEX, $8 \mathrm{~h}=85 \mathrm{~dB}(\mathrm{~A})$ ve ppeak $=140 \mu$ Paii

3) En düşük maruziyet etkin değerleri : LEX, $8 \mathrm{~h}=80 \mathrm{~dB}(\mathrm{~A})$ ve ppeak $=112 \mu$ Paiii

İşçiyi etkileyen maruziyetin belirlenmesinde, işçinin kullandığı kişisel kulak koruyucularının koruyucu etkisi de dikkate alınarak maruziyet sınır değer uygulanmaktadır. Maruziyet etkin değerlerinde kulak koruyucularının etkisi dikkate alınmamaktadır [17].

Uzmanların çoğu, arka arkaya saatler boyunca 85 dB'den fazla sese maruz kalmanın potansiyel olarak tehlikeli olduğunu savunmaktadırlar. Uzun süreli veya aşırı gürültüye maruz kalmanın, stres, zayıf konsantrasyon, işyerinde üretkenlik kayıpları ve iletişim güçlükleri ve uykusuzluktan kaynaklanan yorgunluktan dolayı kalp ve damar hastalıkları, bilişsel bozukluk gibi daha ciddi sorunlara kadar bir dizi sağlık sorununa (kulak çınlaması ve işitme kaybı) neden olduğu gösterilmiş̧ir. Gürültü kirliliğinin psikolojik etkileri, verimliliği olumsuz yönde etkileyen dikkat dağıtıcı ve rahatsılıktır. Çalışmalar, daha yüksek frekanslı gürültüye maruz kalma süresinin uzunluğuna bağlı olarak işçi verimliliğinin azaltılabileceğini göstermiştir. Örneğin, düşük trafik gürültüsü arka plan gürültüisü olarak kabul edilebilirken, alarmlardan veya makinelerden gelen çı̆̆lık sesleri bir eylem çağrısı olarak kabul edilmektedir [18].

Birçok üretim prosesinde olduğu gibi magnezyum metal üretim prosesinde de tozla mücadele, en önemli iş güvenliği konularının başında gelmektedir. Dolomit ocaklarından kalsine dolomit ögütülmesi, pelet oluşumundan redüksiyon cüruflarının yüklenmesi ve boşaltma işlemleri esnasında toz meydana gelmektedir. Ocaklardan gelen dolomit malzemesinin kamyonlarla bunkere boşaltılması esnasında su püskürtme sisteminin devreye girmesi ile tozla mücadele de belli bir aşama kaydedilmiştir. Fakat özellikle magnezyum cürufunun sıcak olması ve su ile tepkimeye girerek alev alması tozla mücadeleyi güçleştirmektedir (Şekil 3). Bu sorun üretim hatlarında gerek toz filtreleme sistemleri ve gerekse yerel cebri çekişli havalandırma yoluyla ortam tozlardan arındırılmakta ve söz konusu havalandırma sistemleri ile minimum seviyeye indirilmektedir. Diğer bir yöntem olarak tozların bulunduğu ortamlarda çalışan işçi sayısı azaltılmakta olup tüm ünitelerde toz toplayıcı ve süpürme makineleri tüm vardiya boyunca görev yapmaktadır. Kaynakta ve ortamda önlemlerin yetersiz kaldığı ve işçilerin bu risklerle yüzleşmek zorunda kaldığı yerlerde, bu alanlarda çalışan işçiler için solunum koruyucu maskeler ve solunum aygitları (respiratörler) kullanılarak tehlikeli tozlarla olan temas kesilmektedir. Yapılan toz ölçümlerine ait sonuçlar tablo 2'de verilmiştir. 


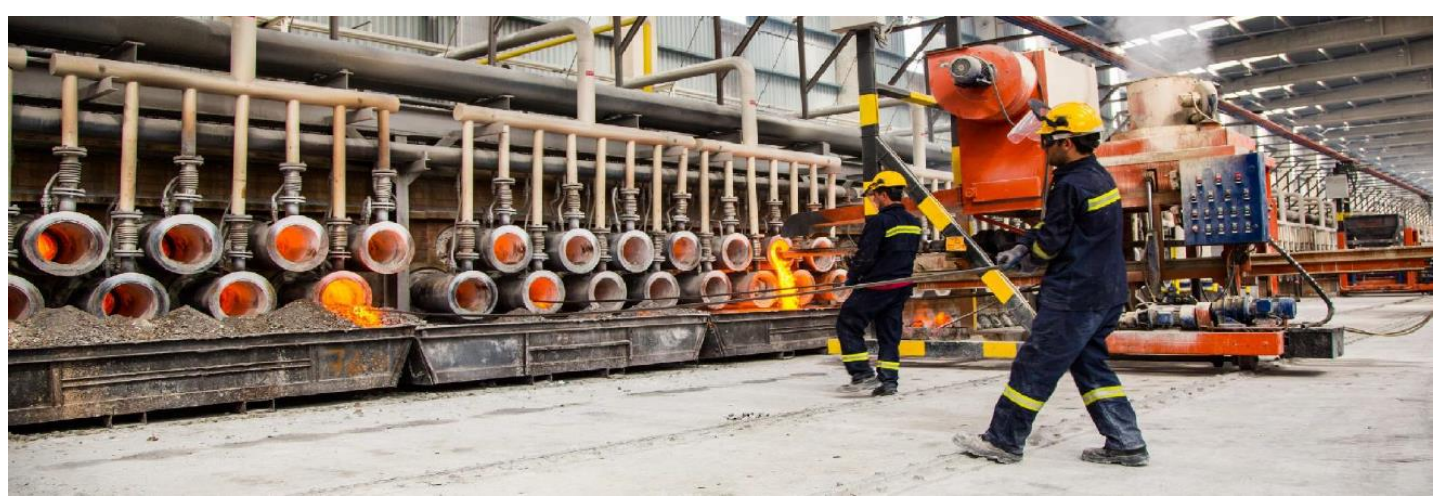

Şekil 3. Magnezyum redüksiyon cüruflarının çekilmesi işlemi

Tablo 2. Magnezyum üretim tesisi toz ölçüm (kişisel maruziyet) sonuçları

\begin{tabular}{cccc} 
Çalışma Yeri & $\begin{array}{c}\text { Akıs hızı } \\
(\boldsymbol{L} / \boldsymbol{d} \boldsymbol{k})\end{array}$ & $\begin{array}{c}\text { Solunabilir toz konsantrasyonu } \\
\text { TWA/ZAOD }\left(\boldsymbol{m g} / \boldsymbol{m}^{\mathbf{3}}\right)\end{array}$ & $\begin{array}{c}\text { Sınır Değer } \\
\text { TWA/ZAOD }\left(\boldsymbol{m g} / \boldsymbol{m}^{\mathbf{3}}\right)\end{array}$ \\
\hline Ham madde/Değirmen Saha & 1,7 & 3,6249 & 5 \\
\hline Redüksiyon & 1,7 & 3,4256 & 5 \\
\hline Rafinasyon & 1,7 & 3,1423 & 5
\end{tabular}

Toz emisyonları kaynağında kontrol edilebilir ve yok edilebilirse, daha geniş bir çalışma ortamı sağlanacak ve toz çıkışı önlenecektir. Üretim ortamında hiç toz olmaması veya daha az toz oluşması, bakım işlerinin en aza indirileceği anlamına gelir. Ayrıca, makinelerin tozla tıkanmadan bozulmadan üretim kaybı yaratmadan daha verimli çalışacakları anlamına da gelir. Böylece bakım masraflarından tasarruf sağlanacak ve arıza maliyetleri önlenerek üretim süreci daha verimli hale gelecektir. Makinelere operatör müdahalesi azalacak ve üretim ve işletme giderlerinden tasarruf sağlanacaktır.

Magnezyum metal üretimi sıcak çalışma ortamının doğasında bulunan başka bir tehlikeyi yani 1sı stresini içermektedir. Vücudun aşırı ısınmasından dolayı stres altında ortaya çıkan 1sı stresi, baş ağrısı ve baş dönmesinden mide bulantısına, sıcak bitkinliğine ve sıcak çarpmasına kadar rahatsızlıkları içerebilmektedir. Isı stresi belirtileri iş performansını olumsuz etkileyebilmekte ve düşük üretkenliğe ve dikkatsiz ve maliyeti yüksek hatalara yol açabilmektedir. Başlangıçtan itibaren uygun termal KKD'yi giymek, 1s1 stresinin magnezyum metal üretim işçilerini etkilemesini önlemenin zahmetsiz bir yoludur ve başka tehlikelerin de sorun haline gelmesini önlemektedir.

Magnezyum üretim tesisinde gerek dolomitin kalsinasyon işlemleri sırasında gerekse redüksiyon prosesleri esnasında işçiler $1200-1250{ }^{\circ} \mathrm{C}$ arasında değişen yüksek sıcaklıklara maruz kalmaktadırlar. İnsanların iç sıcaklıklarını olabildiğince $37^{\circ} \mathrm{C}$ ' ye yakın tutması ve düzenlemesi gerekir. 'Normal' sıcaklık aralığından farklı herhangi bir önemli sapma performansta düşüşe, hastalığa neden olabilmekte ve sonuçta ölüme yol açabilmektedir. Isı stresi tehlikesi, yeterli sıvı alımı, yeterli havalandırma, 1sı kalkanlarının ve koruyucu giysilerin kullanılması ve dinlenmek veya daha serin bir görevde çalışmak için periyodik molalar ile azaltılmalıdır [19]. Magnezyum metal üretim fabrikasında sıcakla temas halinde çalışan işçilere 2 saatte yarım saat mola ve 4 saatte ise vardiya değişmelerine imkan tanınmaktadır. Bu sayede işçilerin sıcak ile temasları olabildiğince kontrol altında tutulmaktadır. Ayrıca çalışan işçilerin elbiseleri terleme esnasında kuru ve temiz yeni elbiseler ile değiştirilmektedir. Sicak alanda çalışan işçilerin bulunduğu yerlerin havalandırmasının istikrarı sağlanarak sürekli takip ve kontrol edilerek termal konfor şartları olabildiğince maksimum seviyede tutulmaktadır. Alınan bu önlemler sayesinde 2017 yılı itibari ile magnezyum üretim tesisi iş yeri hekimine termal konfor yetersizliği nedeniyle her hangi bir işçiden hastalık şikâyeti başvurusu yapılmamıştır. Bunun en büyük nedeni işçilerin sürekli takip edilmesi ve sık geri bildirimlerle süreçlerin kontrol altında tutulmasına bağlanmaktadır. 


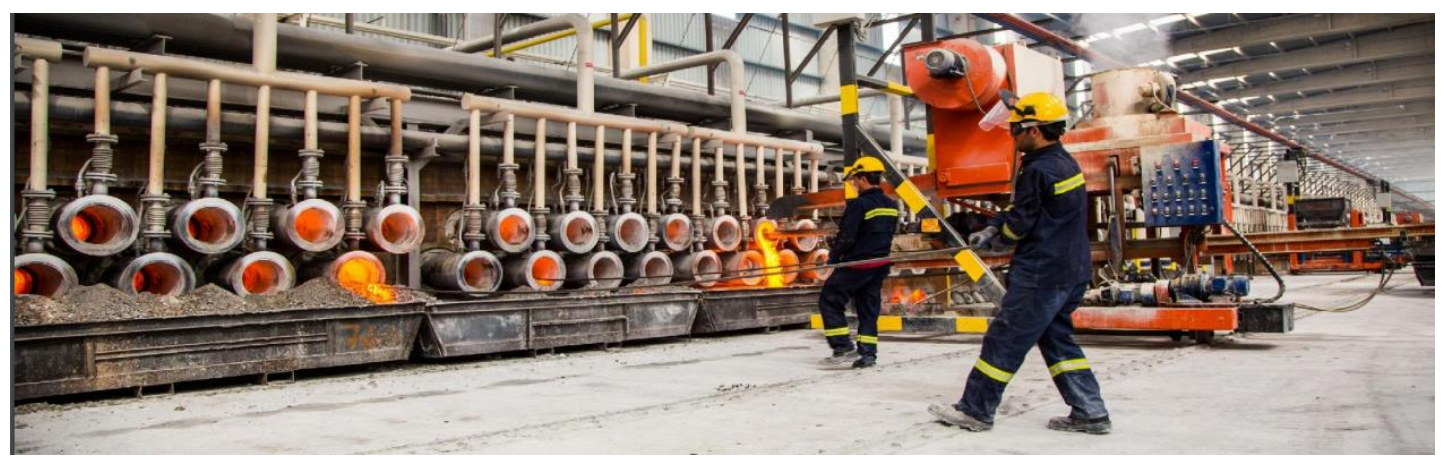

Şekil 4. Redüksiyon firınlarl (slcaklık 1200-1250 ${ }^{\circ} \mathrm{C}$ )

Magnezyum üretim tesisinde yapılan manuel işlemler el-kol titreşimi ve ergonomik sorunlara neden olabilmektedir (Şekil 4). Tüm mesleki maruziyetlerde olduğu gibi, titreşime karşı bireysel duyarlılık kişiden kişiye değişmektedir. Titreşim kaynaklı sağlık koşulları yavaş ilerlemektedir. Başlangıçta genellikle bir ağrı olarak başlar. Titreşime maruz kalma devam ettikçe, ağrı bir yaralanma veya hastalığa dönüşebilmektedir. Magnezyum üretim fabrikasında titreşime bağlı herhangi bir rahatsızlık görülmemiştir. Bunun en büyük nedeni titreşime maruz kalan işçilerin birbirleri ile ikame edilerek çalıştırılması, fabrikanın otomasyon sistemi kullanması ve uzaktan kumanda edilmesidir.

6331 sayılı iş güvenliği kanunun titreşim Titreşim Yönetmeliği maruziyet sınır değerleri ve maruziyet eylem değerleri aşağıda verilmiştir [20].

a) El-kol titreşimi için;

1) Sekiz saatlik çalışma süresi için günlük maruziyet sınır değeri: $5 \mathrm{~m} / \mathrm{s}^{2}$.

2) Sekiz saatlik çalışma süresi için günlük maruziyet eylem değeri: $2,5 \mathrm{~m} / \mathrm{s}^{2}$.

b) Bütün vücut titreşimi için;

1) Sekiz saatlik çalışma süresi için günlük maruziyet sınır değeri: $1,15 \mathrm{~m} / \mathrm{s}^{2}$.

2) Sekiz saatlik çalışma süresi için günlük maruziyet eylem değeri: $0,5 \mathrm{~m} / \mathrm{s}^{2}$.

Yüksek firınlar, dönüştürücüler ve kok fırınları, metal üretimi sürecinde büyük miktarlarda gaz üretmektedir. Karbon monoksit bazen yüksek firınların üst kısımlarından veya gövdelerinden veya tesislerin içindeki birçok gaz boru hattından yayılmakta veya sızmakta ve kazara akut karbon monoksit zehirlenmesine neden olmaktadır. Bu tür zehirlenme vakalarının çoğu, yüksek fırınların etrafındaki çalışma sırasında, özellikle de onarımlar sırasında meydana gelmektedir. Diğer durumlar, firın gövdeleri etrafında inceleme turları, fırın üstlerinin yakınında çalışma veya cüruf çentikleri veya akıtma çentikleri yakınında çalışma sırasında meydana gelmektedir. Karbon monoksit zehirlenmesi, metal üretim tesisleri veya haddehanelerdeki su sızdırmaz vanalardan veya sızdırmaz kaplardan salınan gazdan da kaynaklanabilir; üfleme ekipmanının, kazan dairelerinin veya havalandırma fanlarının aniden kapanmasından; sızıntıdan; işten önce proses kaplarının, boru hatlarının veya ekipmanın düzgün şekilde havalandırılmaması veya boşaltılmaması; ve boru vanalarının kapanması sırasında görülmektedir [20].

Kimyasal madde, işyerinde sıvı, katı (partiküller dahil) veya gaz (buhar, aerosol) formunda bulunabilen bir bileşik veya karışımdır. Bu maddeler, vücutla temas veya vücut tarafindan emilim sonucu tehlike arz edebilir. Emilim deri yoluyla, yutulduğunda veya solunduğunda ortaya çıkabilir. Kimyasal ve biyolojik tehlikelere karşı solunum koruması, magnezyum metal üretim endüstrisindeki işçilerin sağlığını korumak için çok önemlidir. Kaynak dumanları, boyada bulunan veya patlatma için kullanılan kimyasal maddeler, metal dumanı ateşi, kronik bronşit, pulmoner fibroz, astım ve çeşitli tümör türleri gibi akut solunum yolu hastalıklarına yol açabilmekte ve proses sürecinde açığa çıkan partiküller, işçilerin solunum sistemi için bir risk oluşturabilmektedir [21].

Tehlikeli kimyasala maruz kalma, yanlışlıkla yutulursa cilde ve akciğerler üzerinde olumsuz etkilere neden olabilmektedir. Magnezyum metal üretiminde en fazla kimyasal gazlara rafinasyon ünitesinde taç magnezyum ergitme ve döküm işlerinde maruz kalınmaktadır (Şekil 5). Özellikle bu ünitelerde çalışan işçiler koruyucu giysiler giyerek ve kimyasalları doğru şekilde kullanarak gerekli kullanım ve güvenlik 
talimatlarının oluşturulması ve uygulanması ile işçilerin tehlikeli sıvı veya dumanla temaslarından korunmaları sağlanmaktadır.

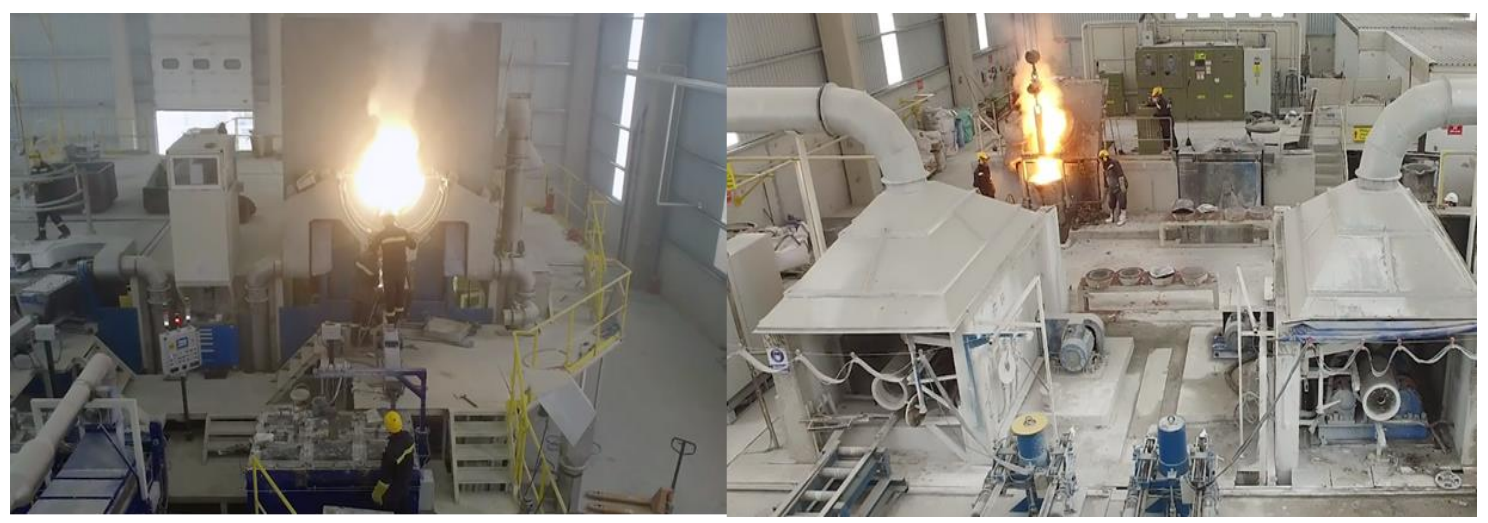

Şekil 5. Magnezyum metal fabrikası rafinasyon ünitesi magnezyum ergitme işleri

Kimyasal güvenlik amaçlı, korunma tedbirleri iş süresi ile sınırlı kalmayıp vardiya bitiminden sonra, kişisel koruyucu ekipmanlar çöp kutusuna atılmakta veya kirli iş elbiseleri izole edilmiş bir sepette saklanmaktadır. Metal üretim işleri esnasında kimyasallarla temas eden hiçbir malzemenin hiçbir şekilde işçiler tarafından eve götürülmesine (kimyasal madde içeren malzemeler işyerinde veya aracın özel bir bölmesinde saklanmamalıdır) izin verilmemektedir. Kimyasal maruziyet belirtileri için işçiler sik sık kontrol edilmekte ve işçilerin sağlığındaki herhangi bir değişiklik olup olmadığı takip edilmektedir. İşçilerin kimyasal kontaminasyondan etkilenildiği düşünüldüğünde vardiya sorumluları, ünite mühendisleri tarafından semptomlar titizlikle gözlenmekte, takip edilmekte ve olası bir belirti durumunda işyeri hekimine kimyasal tehlikeye maruz kalan işçiler götürülerek tedavilerine ivedilikle başlanmaktadır.

Pek çok ciddi dökümhane kazası, dökümhane iş̧̧ilerinin potalardaki eriyiklerin yakınına geldiğinde firın şarjı esnasında meydana gelmektedir. Islak veya nemli hurdaların neden olduğu büyük hurda parçalarının ve su/erimiş metal patlamalarının düşmesinden kaynaklanan sıçramalar, kurutma ve ön 1sıtma sistemleri ve uzaktan kumandalı şarj sistemleri kullanılarak azaltılabilmektedir. Ancak bu sistemler, teneke kutulardaki yağ gibi sıkışmış sıvıları çıkaramaz. Bu tür malzeme Erimiş metallerle çalışmak için risk seviyeleri meydana gelebilecek olay türleri ve işçilerin maruz kalabileceği erimiş metal seviyesi aşağıdaki şekilde ayrıştırılabilinir:

Seviye 0 - kıvılcımlar ve kaynak ve alevle kesme gibi diğer nispeten düşük riskli kullanımlar Seviye 1 - küçük dökülmelerden vb. kaynaklanan erimiş metal sıçramaları

Seviye 2 - küçük bir su/erimiş metal patlamasından kaynaklanan erimiş metal damlacıkları bulutu Seviye 3 - büyük bir patlama veya patlamadan kaynaklanan yerel etki.

Koruyucu kıyafetler mutlaka tam koruma sağlamaz, ancak herhangi bir yaralanmanın şiddetini azaltabilir. İşyerleri, süreçler ve ürünler için koruyucu kıyafetler farklılıklar içermektedir. Sıcak eriyikle çalışacak işçilere hangi koruyucu giysinin sağlanacağına karar verilmesine yardımcı olmak için, erimiş metalle yapılan herhangi bir işin risklerinin değerlendirilmesi gerekmektedir. Erimiş metal ile çalışılması sonucu oluşabilecek riskler tablo 3'de verilmiştir. Genel olarak metal sıçrama ve firın patlamalarının başlıca nedenleri;

a. islak veya nemli malzeme.

b. ağır yük malzemesinin erimiş bir banyoya atılması.

c. 1slak veya nemli aletler veya katkı maddeleri ile çalışmak

d. mühürlü hurda veya santrifüj döküm hurda ruloları kullanımı

Magnezyum üretiminde en büyük risk sudur. Su, nem veya herhangi bir sıv1 erimiş metal ile temas ettiğinde buhara dönüşür ve patlama yaratabilir. Bu tür bir tehlike, çalışanları ve alandaki herkesi, ciddi veya ölümcül yanıklara neden olabilecek yüksek sıcaklıktaki sıvılara ve malzemelere maruz bırakabilir. 
Tehlikeli bir sıçrama veya patlama sadece erimiş metal ile sınırlı değildir, eğer sıcak bir firın su dolu kaplara maruz kalırsa, örneğin ortaya çıkan patlama aynı derecede tehlikeli olabilir. Erimiş metal sıçraması, ciddi yaralanmalara ve ölümlere neden olabilecek bir tehlikedir, çünkü bir metal işçisinin vücudunun herhangi bir kısmı bu tehlikeye tepeden tırnağa maruz kalabilir. Sıçrama ve kıvılcımlar giysilere yapışabilir ve yanabilir, bu nedenle bu ortamlardaki çalışanların uygun erimiş metal KKD 'ye sahip olmaları önemlidir.

Erimiş metal sıçramasının ötesinde, sadece erimiş metallerin, firınların ve sıcak ekipmanın yakınında çalışmak 1sı stresini tetikleyebilir. İşçileri serin ve kuru tutmak için nem emici teknolojiye sahip erimiş metal korumayı seçmek akıllıca bir karardır. Magnezyum metal üretim aşamalarında tehlikeye sadece işçiler maruz kalmamaktadır. İşçisinden mühendisi, mühendisinden genel müdürüne hatta işverenine kadar tüm tehlikeler her çalışan için ortaktır. Bu nedenle risk değerlendirme çalışmalarında her kademeden personelinin katılımına olanak sağlanarak her temsilcinin görüş ve önerisinin alınması önem taşımaktadır. Magnezyum üretim yapılan bir atölye 'de çalışan malzeme mühendisinin üretim kontrol esnasında magnezyum metal eriyiği sıçraması sonucu oluşan iş kazası yaşamış ve kazaya ilişkin fotoğraflar Şekil 6'da gösterilmiştir.
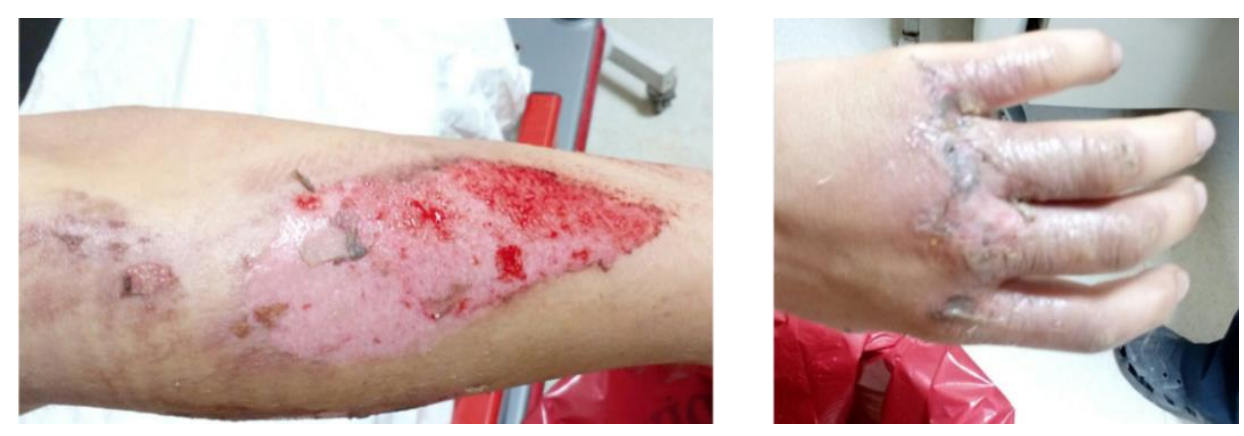

Şekil 6. Magnezyum metal eriği sıçraması sonucu yanma

Erimiş metal sıçraması ve ürettiği 1sı vücudun herhangi bir yerinde ciddi yanık yaralanmalarına neden olabilmektedir. Erimiş metal işlerinde çalışan işçiler, radyant ısıdan ve ayrıca sıvı sıçramasından ve diğer termal tehlikelerden korumak için daima alüminize giysiler giymelidir. Gerek magnezyum metal üretim fabrikasında gerek redüksiyon ünitesinde pelet doldurma ve taç magnezyum alma, magnezyum cürufu boşaltım esnasında gerek rafinasyon ile taç magnezyum ergitme işleri esnasında işçiler daima alüminize koruyucu giysiler giymektedirler.

Alüminize KKD, yüksek ısıya sahip başlıkları, ceketleri, önlükleri, pantolonları, tozlukları, eldivenleri ve daha fazlasını içermektedir. Erimiş metal sıçrama tehlikeleriyle karşı karşıya kalan metal endüstrisi çalışanları için alüminize KKD, işçileri görevine özel bir şekilde korumaktadır. Erimiş metal sıçraması, parçacıklar veya kıvılcımlar, alüminize KKD' nin yüzeyine yapışmamakta ve aleve dayanıklı olduğundan, 1S1 kaynağı çıkarıldığında KKD tutuşmamakta veya yanmaya devam etmemektedir. Alüminize KKD ayrıca 1sıyı koruyucu giysiyi giyen kişiden uzaklaştırarak bu tehlikelere karşı savunmasız görevler sırasında 1sı stresini azaltmaya yardımcı olmaktadır. Alüminize giysinin her bir parçası, erimiş metal sıçraması için ASTM F955 ve radyant 1s1 için ASTM F 1939 ile değerlendirilmelidir. Karbon zırhı alüminize elbiseler, radyan 1sı, kıvılcımlar ve erimiş metal sıçrama tehlikelerine karşı artırılmış koruma sağlar. Öncelikli olarak koruyucu giysiler düşünülmeden önce gereken minimum kontroller aşağıda verilmiştir.

- Dökümhane binasının genel durumu ve onarımı yeterli ve faaliyetler hava etkisinden, özellikle su girişinden korunmalıdır. Zeminler düz ve eşit olacak şekilde korunmalıdır.

- Erimiş metallerin işlendiği geçiş yolları ve diğer alanlar, engellerden ve takılma tehlikelerinden uzak tutulmalıdir.

- Kalıpların ve kalıpların kalitesi, gereksiz erimiş metalin fırlatılmasını veya dışarı çıkmasını önleyecek kadar iyi olmalıdır. 
- Uygun bir çalışma sistemi, su / metal patlamasını önlemek için bir firına şarjın uygun şekilde denetlenmesini, hazırlanmasını ve kurutulmasını takip edecek bir kontrol çizelgesi hazırlanmalıdır.

- Erimiş metal ile kullanılan kalıplar, kepçeler ve aletler uygun şekilde kurutulmalı ve hazırlanmalidır.

- Fırınlar, kepçeler, nakliye yolları ve diğer önemli ekipman öğeleri, arızalarını önlemek için düzenli olarak bakım yapılı ve denetlenmelidir.

- İş, mümkün olan her yerde programlı olarak düzenli yapılmalı, böylece operatörlerin bir eritme veya döküm işlemine yakın çalışmaları engellenmelidir (örneğin, hurda firına otomatik olarak yüklenebilir mi?)

- Bakım çalışmalarının erimiş metale yakın yapılması gerekiyorsa etkili önlemler alınmalıdır. (Operatör eğitimi, çalışanların güvenli çalışma uygulamalarını anlamasını ve takip etmesini sağlamak için tasarlanmalıdır).

- Yerleşik güvenli işletim prosedürlerinin takip edilmesini sağlamak için operasyonlar etkin bir şekilde yönetilmeli ve denetlenmelidir.

- Erimiş metal içeren olaylar araştırılmalı ve dersler çıkarılmalıdır.

- Risk değerlendirmesi yapıldıktan sonra, erimiş metal nedeniyle yaralanma riskini azaltmak için koruyucu giysiler sağlanması gerektiğine karar verilirse, doğru giysinin seçilmesi önemlidir.

\section{MAGNEZYUM ÜRETIM PROSESI RISK DEĞERLENDİRMESI}

Magnezyum üretim tesisinde en yüksek risklerin sıcak temas sonucu ortaya çıktığı görülmektedir. Türkiye'de ilk ve Avrupa'da tek üretim tesisi olan magnezyum üretim tesisinde şu ana kadar ölümcül bir iş kazası yaşanmamıştır. Yaşanılan kazalar sıcak temas sonucu ya da magnezyum eriyik haldeki sıçraması veya yüksek sıcaklıkta çalışıldığından dolayı termal konfor sıcak soğuk dengesinin sağlanamaması sonucu yaşanmaktadır. Türkiye'deki magnezyum tesisinde iş kazalarının en asgari seviyede görülmesinin sebebi çalışanların sürekli bilgilendirilmesi, yurtiçinde bu işi yapan bir kuruluş olmadığ 1 için yurtdışından magnezyum üretimi yapan kurumların iş güvenliği konusunda destek ve tecrübelerini kazanmaları görülmektedir. Ayrıca yine sektörde iş güvenliği ile ilgili ödül sistemi geliştirilmiş olup iş kazasız gün sayısı arttıkça işçilerin iş güvenliği sistemine aitlik duyguları da artmakta ve iş güvenliği kültürü çalışanlar arasında yayılmaktadır.

Tesiste bir ilk olması sebebiyle diğer metal döküm sektörlerinden farklı olarak yaşanabilecek tehlikeler ve iş kazaları olasılıkları Fine Kinney risk metodu ile hesaplanmış olup tablo 3 'de gösterilmiştir.

Fine Kinney risk değerlerdirmesi çalışmaları neticesinde 34 adet risk faktöründen 1'i tolerans gösterilemez risk, 9'u en kısa sürede giderilecek risk, 6's1 esaslı risk, 15'i önemli risk, 2'si olası risk ve 1 'tanesi de önemsiz risk olarak hesap edilmiştir. Tespit edilen risklerden en önemlisi yani tolerans gösterilemez risk; elek altı mg atıklarının stoklanması esnasında magnezyum metalinin içten yanması sonucu yangın ve patlama sonucu ölümcül kazaların yaşanabilmesi ve bu durumdan tüm çalışanların etkilenebilmesidir. Burada en belirleyici olan faktör hemem hemen sürekli ve her saate birkaç defa tehlikeye maruz kalma durumudur. En kısa sürede giderilmesi gereken risklerin başında, ergitme potolarına çalışanın düşmesi nedeniyle ergimiş metale maruziyet sonucu meydana gelen ciddi yanıklar (ölümlü iş kazası); Taç mg besleme işi esnasında ergimiş mg sıçraması sonucu ergimiş metale maruziyet ciddi yanıklar (yanık - uzuv kaybı); metal aktarma potasının devrilmesi sonucu sıcak metalik eriyik yayılması, platform üzerinde çalışan personelin zehirli gaza maruz kalması sonucu zehirlenme, sıcak el aletlerine vücut teması gibi tehlike kaynakları gelmektedir.

Yapılan tüm bu tespit, kontrol ve önleme çalışmaları sonucunda \%91,42 oranında risk seviyesinde azalma gerçekleşmiştir. Tüm metal üretim tesislerinde olduğu gibi magnezyum üretim tesisinde de önlemlerin alınmasına rağmen hala önemli risklerin var olduğu ve etkin bir iş güvenliği ile risklerin azaltılabilineceği görülmektedir. 
Tablo 3. Risk değerlendirme tablosu

\begin{tabular}{|c|c|c|c|c|c|c|c|c|c|c|c|c|c|c|c|}
\hline \multicolumn{2}{|c|}{ BÖLÜM } & TEHLIKKE & \multicolumn{7}{|c|}{$\begin{array}{c}\text { RİSK } \\
\text { (Tehlikeden kaynaklanacak kayıp, yaralanma ya da başka zararlı sonuç meydana } \\
\text { gelme ihtimali) }\end{array}$} & \multicolumn{6}{|c|}{$\begin{array}{l}\text { RISSK KONTROL TEDBİRİ SONRASI } \\
\text { DEĞERLENDİRME }\end{array}$} \\
\hline $\begin{array}{l}0 \\
\frac{1}{2} \\
\frac{\pi}{2}\end{array}$ & 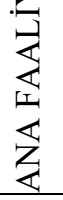 & $\begin{array}{l}\text { TEHLİKE } \\
\text { KAYNAĞI }\end{array}$ & 当 & 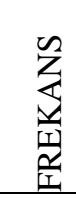 & 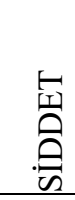 & 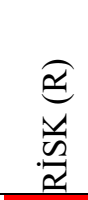 & 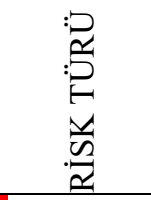 & RİSK & $\begin{array}{l}\text { ALINMASI GEREKEN } \\
\text { ÖNLEMLER }\end{array}$ & 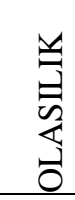 & $\frac{\sqrt{Z}}{\mathbb{Z}}$ & 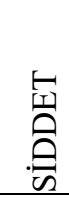 & 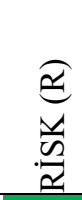 & 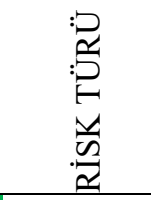 & $\begin{array}{l}\text { RİSK } \\
\text { AÇIKLAMA }\end{array}$ \\
\hline 1 & 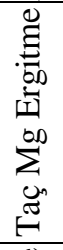 & $\begin{array}{l}\text { Ergitme } \\
\text { potalarına } \\
\text { çalışanın } \\
\text { düşmesi }\end{array}$ & 3 & 6 & 40 & 720 & $\begin{array}{l}\text { En kısa } \\
\text { sürede } \\
\text { giderile- } \\
\text { cek risk }\end{array}$ & $\begin{array}{l}\text { Ölümlü kaza- } \\
\text { ciddi çevresel } \\
\text { zarar }\end{array}$ & $\begin{array}{l}\text { Tüm ergitme potaları } \\
\text { platform üzerinde zemine } \\
\text { sıfır konumlandırılmıştır. } \\
\text { Potalar üzerine düşmeyi } \\
\text { önleyici kapaklar } \\
\text { yapılmalıdır. }\end{array}$ & 1 & 6 & 7 & 42 & $\begin{array}{l}\text { Olas1 } \\
\text { risk }\end{array}$ & $\begin{array}{l}\text { Gözetim altında } \\
\text { uygulanmalıdır. }\end{array}$ \\
\hline 2 & 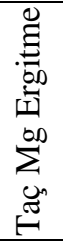 & $\begin{array}{l}\text { Ergitme } \\
\text { işlemi } \\
\text { esnasında } \\
\text { ergimiş metal } \\
\text { sıçramaları }\end{array}$ & 3 & 6 & 15 & 270 & $\begin{array}{l}\text { Esasl1 } \\
\text { risk }\end{array}$ & $\begin{array}{l}\text { Kalıcı hasar/ } \\
\text { Yaralanma- iş } \\
\text { kaybı }\end{array}$ & $\begin{array}{l}\text { Çalışanlara ısıya dayanıklı } \\
\text { alüminize kıyafetler } \\
\text { zimmetlenmelidir. Sıvı } \\
\text { metale uygulanan azot gazı } \\
\text { miktarı } 2 \text { barı geçmemelidir. }\end{array}$ & 1 & 6 & 15 & 90 & $\begin{array}{l}\text { Önemli } \\
\text { risk }\end{array}$ & $\begin{array}{l}\text { Uzun dönemde } \\
\text { iyileştirilmelidir. }\end{array}$ \\
\hline 3 & 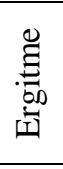 & $\begin{array}{l}\text { Sivı metal } \\
\text { içerisine islak } \\
\text { hurda } \\
\text { atılması }\end{array}$ & 1 & 6 & 15 & 90 & $\begin{array}{l}\text { Önemli } \\
\text { risk }\end{array}$ & $\begin{array}{l}\text { Uzun } \\
\text { dönemde } \\
\text { iyileştirilmeli } \\
\text { dir } \\
\end{array}$ & $\begin{array}{l}\text { Çalışan personel uyarılmalı } \\
\text { ve hurda metal dış ortamda } \\
\text { stoklanmamalıdır }\end{array}$ & 0,2 & 2 & 40 & 16 & $\begin{array}{l}\text { Önemsiz } \\
\text { risk }\end{array}$ & $\begin{array}{l}\text { Önlem } \\
\text { öncelikli } \\
\text { değildir. }\end{array}$ \\
\hline 4 & 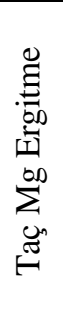 & $\begin{array}{l}\text { İndüksiyon } \\
\text { ocağı ocak } \\
\text { astarı dövme } \\
\text { veya astar } \\
\text { bozma } \\
\text { işlemlerinde } \\
\text { toza } \\
\text { maruziyet }\end{array}$ & 3 & 3 & 15 & 135 & $\begin{array}{l}\text { Önemli } \\
\text { risk }\end{array}$ & $\begin{array}{l}\text { Uzun } \\
\text { dönemde } \\
\text { iyileştirilmeli } \\
\text { dir }\end{array}$ & $\begin{array}{l}\text { KKD tablosunda yer alan } \\
\text { standartlara uygun KKD } \\
\text { kullanılmalidir. }\end{array}$ & 0,5 & 2 & 15 & 15 & $\begin{array}{l}\text { Önemsiz } \\
\text { risk }\end{array}$ & $\begin{array}{l}\text { Önlem } \\
\text { öncelikli } \\
\text { değildir. }\end{array}$ \\
\hline
\end{tabular}




\begin{tabular}{|c|c|c|c|c|c|c|c|c|c|c|c|c|c|c|c|}
\hline 5 & 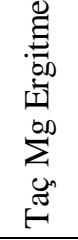 & $\begin{array}{l}\text { Tüm ergitme } \\
\text { ocakların } \\
\text { bakımları } \\
\text { periyodik } \\
\text { yapılmaması }\end{array}$ & 3 & 6 & 15 & 270 & $\begin{array}{l}\text { Esasli } \\
\text { risk }\end{array}$ & $\begin{array}{l}\text { Kalıcı } \\
\text { hasar/yaralan } \\
\text { ma- iş kaybı }\end{array}$ & $\begin{array}{l}\text { Ergitme ocakları için } \\
\text { periyodik bakım çizelgeleri } \\
\text { oluşturulmalıdır ve } \\
\text { çalışmalar kayıt altına } \\
\text { alınmalıdır. }\end{array}$ & 1 & 6 & 15 & 90 & $\begin{array}{l}\text { Önemli } \\
\text { risk }\end{array}$ & $\begin{array}{l}\text { Uzun dönemde } \\
\text { iyileştirilmelidir. }\end{array}$ \\
\hline 6 & 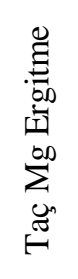 & $\begin{array}{l}\text { Ergitme } \\
\text { ocağ1 } \\
\text { platformlar1 } \\
\text { üzerinde } \\
\text { düzensiz } \\
\text { malzeme } \\
\text { istiflenmesi }\end{array}$ & 3 & 10 & 15 & 450 & $\begin{array}{l}\text { En kısa } \\
\text { sürede } \\
\text { giderile- } \\
\text { cek risk }\end{array}$ & $\begin{array}{l}\text { Kalıcı } \\
\text { hasar/yaralan } \\
\text { ma- iş kaybı }\end{array}$ & $\begin{array}{l}\text { Platformlar üzerinde gereksiz } \\
\text { malzeme istiflenmesi } \\
\text { engellenmelidir. Kullanılan } \\
\text { el aletlerinin yere } \\
\text { bırakılmaması için uygun } \\
\text { alanlar tesis edilmelidir. }\end{array}$ & 1 & 10 & 7 & 70 & $\begin{array}{l}\text { Önemli } \\
\text { risk }\end{array}$ & $\begin{array}{l}\text { Uzun dönemde } \\
\text { iyileştirilmelidir. }\end{array}$ \\
\hline 7 & 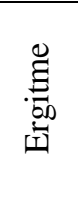 & $\begin{array}{l}\text { Basınçlı } \\
\text { tüplerin } \\
\text { forklift } \\
\text { çatallarında } \\
\text { taşınması }\end{array}$ & 3 & 2 & 100 & 600 & $\begin{array}{l}\text { En kısa } \\
\text { sürede } \\
\text { giderile- } \\
\text { cek risk }\end{array}$ & $\begin{array}{l}\text { Birden fazla } \\
\text { ölümlü kaza- } \\
\text { çevresel } \\
\text { felaket }\end{array}$ & $\begin{array}{l}\text { Basınçlı tüpler forklift ile } \\
\text { taşınacaksa, tüplerin dik } \\
\text { şekilde bağlandığı taşıma } \\
\text { ekipmanları kullanılmalıdır. }\end{array}$ & 0,5 & 2 & 100 & 100 & $\begin{array}{l}\text { Önemli } \\
\text { risk }\end{array}$ & $\begin{array}{l}\text { Uzun dönemde } \\
\text { iyileştirilmelidir }\end{array}$ \\
\hline 8 & 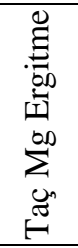 & $\begin{array}{l}\text { Taç mg } \\
\text { besleme } \\
\text { esnasinda } \\
\text { ergimiş mg } \\
\text { sıçraması }\end{array}$ & 6 & 6 & 15 & 540 & $\begin{array}{l}\text { En kısa } \\
\text { sürede } \\
\text { giderile- } \\
\text { cek risk }\end{array}$ & $\begin{array}{l}\text { Kalıcı } \\
\text { hasar/yaralan } \\
\text { ma- iş kaybı }\end{array}$ & $\begin{array}{l}\text { Besleme işi yapan çalışanlara } \\
\text { yüz siperliği } \\
\text { kullandırılmalıdır. Besleme } \\
\text { olukları yapılarak çalışanın } \\
\text { tehlikeli bölgeye yaklaşması } \\
\text { önlenmelidir. }\end{array}$ & 1 & 10 & 3 & 30 & Olası risk & $\begin{array}{l}\text { Gözetim altında } \\
\text { uygulanmalıdır. }\end{array}$ \\
\hline 9 & 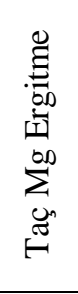 & $\begin{array}{l}\text { Platform } \\
\text { üzerinde } \\
\text { çalışan } \\
\text { personelin } \\
\text { zehirli gaza } \\
\text { maruz } \\
\text { kalması }\end{array}$ & 10 & 10 & 7 & 700 & $\begin{array}{l}\text { En kısa } \\
\text { sürede } \\
\text { giderile- } \\
\text { cek risk }\end{array}$ & $\begin{array}{l}\text { Önemli hasar } \\
\text { / yaralanma- } \\
\text { dış ilkyardım }\end{array}$ & $\begin{array}{l}\text { Çalışanlar oksijen destekli } \\
\text { tam yüz maskesi } \\
\text { kullanmalıdır. Ortamdan } \\
\text { çıkan gazın tahliye edilmesi } \\
\text { ortamdan uzaklaştırılmasını } \\
\text { sağlayan havalandırma } \\
\text { tertibatı kurulmalıdır. }\end{array}$ & 1 & 10 & 3 & 30 & Olası risk & $\begin{array}{l}\text { Gözetim altında } \\
\text { uygulanmalıdır. }\end{array}$ \\
\hline 10 & 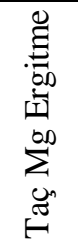 & $\begin{array}{l}\text { Sicak el } \\
\text { aletlerine } \\
\text { vücut temas1 }\end{array}$ & 10 & 6 & 7 & 420 & $\begin{array}{l}\text { En kısa } \\
\text { sürede } \\
\text { giderile- } \\
\text { cek risk }\end{array}$ & $\begin{array}{l}\text { Önemli hasar } \\
\text { / yaralanma- } \\
\text { dış ilkyardım }\end{array}$ & $\begin{array}{l}\text { Sicak el aletleri } \\
\text { kullanıldıktan sonra beli bir } \\
\text { alanda tutulmalıdır bu alanda } \\
\text { sicak yüzey uyarı levhaları } \\
\text { asılı olmalıdır. }\end{array}$ & 1 & 6 & 7 & 42 & Olası risk & $\begin{array}{l}\text { Gözetim altında } \\
\text { uygulanmalıdır. }\end{array}$ \\
\hline
\end{tabular}




\begin{tabular}{|c|c|c|c|c|c|c|c|c|c|c|c|c|c|c|c|}
\hline 11 & 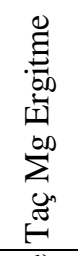 & $\begin{array}{l}\text { Ocak } \\
\text { üzerinde siv1 } \\
\text { malzemelerin } \\
\text { stoklanması }\end{array}$ & 3 & 3 & 15 & 135 & $\begin{array}{l}\text { Önemli } \\
\text { risk }\end{array}$ & $\begin{array}{l}\text { Kalıcı } \\
\text { hasar/yaralan } \\
\text { ma- iş kaybı }\end{array}$ & $\begin{array}{l}\text { Ocakların yer aldığı } \\
\text { platformlar üzerinde sıvı } \\
\text { maddelerin stoklanması } \\
\text { engellenmelidir. Çalışanlar } \\
\text { uyarılmalıdır. Sürekli } \\
\text { kontroller sağlanmalıdır. }\end{array}$ & 1 & 3 & 15 & 45 & Olası risk & $\begin{array}{l}\text { Gözetim altında } \\
\text { uygulanmalıdır. }\end{array}$ \\
\hline 12 & 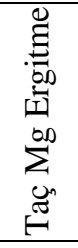 & $\begin{array}{l}\text { Elek altı } \mathrm{Mg} \\
\text { atıklarının } \\
\text { stoklanması }\end{array}$ & 6 & 10 & 40 & 2400 & $\begin{array}{l}\text { Tolerans } \\
\text { gösterile- } \\
\text { mez risk }\end{array}$ & $\begin{array}{l}\text { Ölümlü kaza- } \\
\text { ciddi çevresel } \\
\text { zarar }\end{array}$ & $\begin{array}{l}\text { Anti statik naylonlar içinde } \\
\text { stoklanmalıdır. Mümkün } \\
\text { olduğunca sıcak ortamdan } \\
\text { uzakta stoklanmalı ve en kısa } \\
\text { sürede bertaraf edilmelidir. }\end{array}$ & 0,5 & 2 & 40 & 40 & Olası risk & $\begin{array}{l}\text { Gözetim altında } \\
\text { uygulanmalıdır. }\end{array}$ \\
\hline 13 & 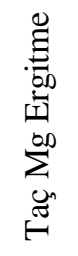 & $\begin{array}{l}\text { Ergimişs sıv1 } \\
\text { metal içine } \\
\text { soğuk el } \\
\text { aletlerinin } \\
\text { temas etmesi }\end{array}$ & 1 & 6 & 15 & 90 & $\begin{array}{l}\text { Önemli } \\
\text { risk }\end{array}$ & $\begin{array}{l}\text { Kalıcı } \\
\text { hasar/yaralan } \\
\text { ma- iş kaybı }\end{array}$ & $\begin{array}{l}\text { El aletleri kullanılmadan } \\
\text { önce 1st1ılmalıdır. Çalışanlar } \\
\text { mesleki eğitimlerde konu } \\
\text { hakkında bilgilendirilmelidir. } \\
\text { Ayrıca uyarı levhaları } \\
\text { asılmalıdır. }\end{array}$ & 0,5 & 6 & 15 & 45 & Olası risk & $\begin{array}{l}\text { Gözetim altında } \\
\text { uygulanmalıdır. }\end{array}$ \\
\hline 14 & 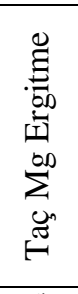 & $\begin{array}{l}\text { İndüksiyon } \\
\text { ocağı } \\
\text { kaynaklı iş } \\
\text { kazaları }\end{array}$ & 0,5 & 6 & 40 & 120 & $\begin{array}{l}\text { Önemli } \\
\text { risk }\end{array}$ & $\begin{array}{l}\text { Uzun } \\
\text { dönemde } \\
\text { iyileștirilmeli- } \\
\text { dir. }\end{array}$ & $\begin{array}{l}\text { İndüksiyon ocağı topraklama } \\
\text { kontrolleri yılda bir } \\
\text { yapplmalı gerekli görüldüğü } \\
\text { hallerde kontroller } \\
\text { siklaştırılmalıdır. } \\
\text { Potansiyometre \%100'e } \\
\text { sabitlenmelidir. }\end{array}$ & 0,5 & 1 & 40 & 20 & $\begin{array}{l}\text { Önemsiz } \\
\text { risk }\end{array}$ & $\begin{array}{l}\text { Önlem } \\
\text { öncelikli } \\
\text { değildir. }\end{array}$ \\
\hline 15 & 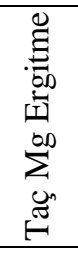 & $\begin{array}{l}\text { Azot tank1 } \\
\text { basınç }\end{array}$ & 1 & 6 & 40 & 240 & $\begin{array}{l}\text { Esasl1 } \\
\text { risk }\end{array}$ & $\begin{array}{l}\text { Kısa dönemde } \\
\text { iyileştirilmeli- } \\
\text { dir. }\end{array}$ & $\begin{array}{l}\text { Flanş gibi ek yeri olmayan } \\
\text { yanıcı gaz veya sıvı boru } \\
\text { hatları ile sıvı argon ve sıvı } \\
\text { azot depolama tankı } \\
\text { arasındaki uzaklık } 5 \text { m'den } \\
\text { az olmamalıdır. }\end{array}$ & 0,5 & 6 & 7 & 21 & Olası risk & $\begin{array}{l}\text { Gözetim altında } \\
\text { uygulanmalıdır. }\end{array}$ \\
\hline 16 & 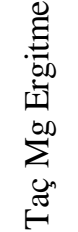 & $\begin{array}{l}\text { Külçe döküm } \\
\text { bandından } \\
\text { külçelerin } \\
\text { düşmesi }\end{array}$ & 3 & 6 & 7 & 126 & $\begin{array}{l}\text { Önemli } \\
\text { risk }\end{array}$ & $\begin{array}{l}\text { Uzun } \\
\text { dönemde } \\
\text { iyileștirilmeli- } \\
\text { dir. }\end{array}$ & $\begin{array}{l}\text { Döküm bandı yerden yüksek } \\
\text { olan son kısmı yere külçenin } \\
\text { düşüşünü yavaşlatacak şut } \\
\text { takılmalıdır. }\end{array}$ & 1 & 6 & 7 & 42 & Olası risk & $\begin{array}{l}\text { Gözetim altında } \\
\text { uygulanmalıdrr. }\end{array}$ \\
\hline
\end{tabular}




\begin{tabular}{|c|c|c|c|c|c|c|c|c|c|c|c|c|c|c|c|}
\hline 17 & 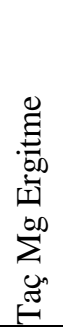 & $\begin{array}{l}\text { Deforme } \\
\text { olmuş taşıma } \\
\text { aparatları } \\
\text { saban zincir } \\
\text { kanca } \\
\text { kullanımı }\end{array}$ & 3 & 6 & 40 & 720 & $\begin{array}{l}\text { En kısa } \\
\text { sürede } \\
\text { giderile- } \\
\text { cek risk }\end{array}$ & $\begin{array}{l}\text { Önlem alması } \\
\text { için işverene } \\
\text { durum en kısa } \\
\text { sürede } \\
\text { bildirilir. }\end{array}$ & $\begin{array}{l}\text { Saban zincir, kanca ve bez } \\
\text { halatlar kontrol talimatları ve } \\
\text { çizelgeleri oluşturulmalı } \\
\text { haftalık kontroller } \\
\text { yapılmalıdır. Yılda bir kez } \\
\text { yetkili makine mühendisi } \\
\text { tarafindan periyodik } \\
\text { kontrolleri yapılmalıdır. }\end{array}$ & 0,5 & 6 & 40 & 120 & $\begin{array}{l}\text { Önemli } \\
\text { risk }\end{array}$ & $\begin{array}{l}\text { Uzun dönemde } \\
\text { iyileştirilmelidir. }\end{array}$ \\
\hline 18 & 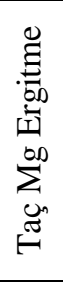 & $\begin{array}{l}\text { Metal } \\
\text { aktarma } \\
\text { potasının } \\
\text { devrilmesi, } \\
\text { Sicak metal } \\
\text { eriyik } \\
\text { yayılması } \\
\end{array}$ & 3 & 10 & 40 & 1200 & Olası & $\begin{array}{l}\text { En kısa } \\
\text { sürede } \\
\text { giderilecek } \\
\text { risk }\end{array}$ & $\begin{array}{l}\text { Çalışanlar yanmaz alüminize } \\
\text { elbise giymeli, tam yüz } \\
\text { maskesi kullanmalı, Uzun el } \\
\text { aletleri kullanmalıdır. }\end{array}$ & 0,5 & 10 & 15 & 75 & $\begin{array}{l}\text { Önemli } \\
\text { risk }\end{array}$ & $\begin{array}{l}\text { Uzun dönemde } \\
\text { iyileştirilmelidir. }\end{array}$ \\
\hline 19 & $\frac{5}{0}$ & $\begin{array}{l}\text { Sivı metal } \\
\text { içerisine islak } \\
\text { hurda } \\
\text { atılması } \\
\text { sonucu metal } \\
\text { sıçraması }\end{array}$ & 1 & 6 & 15 & 90 & $\begin{array}{l}\text { Önemli } \\
\text { risk }\end{array}$ & $\begin{array}{l}\text { Uzun } \\
\text { dönemde } \\
\text { iyileştirilmeli- } \\
\text { dir. }\end{array}$ & $\begin{array}{l}\text { Çalışan personel uyarılmalı } \\
\text { ve hurda metal diş ortamda } \\
\text { stoklanmamalıdır. }\end{array}$ & 0,2 & 2 & 40 & 16 & $\begin{array}{l}\text { Önemsiz } \\
\text { risk }\end{array}$ & $\begin{array}{l}\text { Önlem } \\
\text { öncelikli } \\
\text { değildir. }\end{array}$ \\
\hline 20 & $\begin{array}{l}\frac{5}{0} \\
\frac{0}{0}\end{array}$ & $\begin{array}{l}\text { Ocak astarı } \\
\text { dövme veya } \\
\text { astar bozma } \\
\text { işlemlerinde } \\
\text { toza } \\
\text { maruziyet }\end{array}$ & 3 & 3 & 15 & 135 & $\begin{array}{l}\text { Önemli } \\
\text { risk }\end{array}$ & $\begin{array}{l}\text { Uzun } \\
\text { dönemde } \\
\text { iyileştirilmeli- } \\
\text { dir. }\end{array}$ & $\begin{array}{l}\text { Kkd tablosunda yer alan } \\
\text { standartlara uygun kkd } \\
\text { kullanılmalıdır. }\end{array}$ & 0,5 & 2 & 15 & 15 & $\begin{array}{l}\text { Önemsiz } \\
\text { risk }\end{array}$ & $\begin{array}{l}\text { Önlem } \\
\text { öncelikli } \\
\text { değildir. }\end{array}$ \\
\hline 21 & $\begin{array}{l}\frac{5}{0} \\
\frac{0}{0} \\
\simeq\end{array}$ & $\begin{array}{l}\text { Dişarıdan } \\
\text { alınan } \\
\text { hurdalarda } \\
\text { radyasyona } \\
\text { maruz kalma }\end{array}$ & 0,2 & 1 & 100 & 20 & $\begin{array}{l}\text { Önemsiz } \\
\text { risk }\end{array}$ & $\begin{array}{l}\text { Önlem } \\
\text { öncelikli } \\
\text { değildir. }\end{array}$ & $\begin{array}{l}\text { Radyasyon ölçümü } \\
\text { yapılmadan hurda tedariki } \\
\text { yapılmamalıdır. }\end{array}$ & 0,5 & 0,5 & 15 & 3,75 & $\begin{array}{l}\text { Önemsiz } \\
\text { risk }\end{array}$ & $\begin{array}{l}\text { Önlem } \\
\text { öncelikli } \\
\text { değildir. }\end{array}$ \\
\hline 22 & 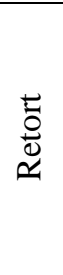 & $\begin{array}{l}\text { İndüskiyon } \\
\text { ocağ1 } \\
\text { Soğutma } \\
\text { sistemi } \\
\text { kaçakları } \\
\text { sonucu } \\
\text { patlama }\end{array}$ & 1 & 6 & 100 & 600 & $\begin{array}{l}\text { En kisa } \\
\text { sürede } \\
\text { giderile- } \\
\text { cek risk }\end{array}$ & $\begin{array}{l}\text { Önlem alması } \\
\text { için İşverene } \\
\text { durum en kısa } \\
\text { sürede } \\
\text { bildirilir. }\end{array}$ & $\begin{array}{l}\text { Önleyici switchler düzenli } \\
\text { kontrol edilmeli ve çalışanlar } \\
\text { uyarılmalıdır. Mesleki } \\
\text { eğitimlerde konu ayrıca ele } \\
\text { alınmalıdır. }\end{array}$ & 1 & 6 & 7 & 42 & Olası risk & $\begin{array}{l}\text { Gözetim altında } \\
\text { uygulanmalıdır. }\end{array}$ \\
\hline
\end{tabular}




\begin{tabular}{|c|c|c|c|c|c|c|c|c|c|c|c|c|c|c|c|}
\hline 23 & $\begin{array}{l}\frac{5}{0} \\
\frac{0}{2} \\
\text { ֻ }\end{array}$ & $\begin{array}{l}\text { Döküm } \\
\text { potası } \\
\text { refrakterlerin } \\
\text { delinmesi ve } \\
\text { ortama sıv1 } \\
\text { metal } \\
\text { yayılması }\end{array}$ & 3 & 1 & 100 & 300 & $\begin{array}{l}\text { Esaslı } \\
\text { risk }\end{array}$ & $\begin{array}{l}\text { Kisa dönemde } \\
\text { iyileştirilmeli- } \\
\text { dir. }\end{array}$ & $\begin{array}{l}\text { Döküm potası kontrol } \\
\text { talimatı oluşturulmalı ve her } \\
\text { kullanım öncesi kontroller } \\
\text { yapılıp kayıt altına } \\
\text { alınmalıdır. }\end{array}$ & 0,5 & 6 & 40 & 120 & $\begin{array}{l}\text { Önemli } \\
\text { risk }\end{array}$ & $\begin{array}{l}\text { Uzun dönemde } \\
\text { iyileştirilmelidir. }\end{array}$ \\
\hline 24 & $\frac{\pi}{0}$ & $\begin{array}{l}\text { Döküm } \\
\text { alanındaki su } \\
\text { herhangi bir } \\
\text { metal } \\
\text { siçraması } \\
\text { durumunda } \\
\text { yaralanmalar } \\
\text { a neden } \\
\text { olması }\end{array}$ & 3 & 6 & 7 & 126 & $\begin{array}{l}\text { Önemli } \\
\text { risk }\end{array}$ & $\begin{array}{l}\text { Uzun } \\
\text { dönemde } \\
\text { iyileştirilmeli- } \\
\text { dir. }\end{array}$ & $\begin{array}{l}\text { Döküm alanında sıvı } \\
\text { bulunmaması için çalışanlar } \\
\text { uyarılmalı ve mesleki } \\
\text { eğitimlerde ayrıca } \\
\text { bilgilendirme yapılmalıdır. } \\
\text { Uyarıcı levhalar döküm } \\
\text { alanında bulunmalıdır. }\end{array}$ & 1 & 2 & 15 & 30 & Olası risk & $\begin{array}{l}\text { Gözetim altında } \\
\text { uygulanmalıdır. }\end{array}$ \\
\hline 25 & $\frac{\pi}{0}$ & $\begin{array}{l}\text { Sodyum } \\
\text { silikatın göze } \\
\text { sıçraması }\end{array}$ & 1 & 6 & 15 & 90 & $\begin{array}{l}\text { Önemli } \\
\text { risk }\end{array}$ & $\begin{array}{l}\text { Uzun } \\
\text { dönemde } \\
\text { iyileştirilmeli- } \\
\text { dir. }\end{array}$ & $\begin{array}{l}\text { Çalışma alanında göz duşları } \\
\text { konulmalı ve çalışanlar göz } \\
\text { duşu kullanımı konusunda } \\
\text { eğitilmelidir. }\end{array}$ & 0,5 & 2 & 7 & 7 & $\begin{array}{l}\text { Önemsiz } \\
\text { risk }\end{array}$ & $\begin{array}{l}\text { Önlem } \\
\text { öncelikli } \\
\text { değildir. }\end{array}$ \\
\hline 26 & $\frac{\pi}{0}$ & $\begin{array}{l}\text { Retort dibi } \\
\text { dökümünün } \\
\text { ardından } \\
\text { yanıkların } \\
\text { oluşması }\end{array}$ & 3 & 2 & 7 & 42 & $\begin{array}{l}\text { Olas1 } \\
\text { risk }\end{array}$ & $\begin{array}{l}\text { Gözetim } \\
\text { altında } \\
\text { uygulanmal1- } \\
\text { dır. }\end{array}$ & $\begin{array}{l}\text { Retort dipleri için kapak } \\
\text { yapılmalıdır. }\end{array}$ & 1 & 3 & 7 & 21 & Olası risk & $\begin{array}{l}\text { Gözetim altında } \\
\text { uygulanmalıdır. }\end{array}$ \\
\hline 27 & $\begin{array}{l}\frac{1}{0} \\
\frac{0}{2} \\
2\end{array}$ & $\begin{array}{l}\text { Isıtıcının } \\
\text { altında pota } \\
\text { olmadan } \\
\text { çalıştırılma } \\
\text { sonucu yanık } \\
\text { oluşması } \\
\end{array}$ & 3 & 3 & 15 & 135 & $\begin{array}{l}\text { Önemli } \\
\text { risk }\end{array}$ & $\begin{array}{l}\text { Uzun } \\
\text { dönemde } \\
\text { iyileştirilmeli- } \\
\text { dir. }\end{array}$ & $\begin{array}{l}\text { Çalışanlar uyarılmalı uyarı } \\
\text { levhaları asılmalı ve çalışma } \\
\text { talimatlı hazırlanmalıdır. }\end{array}$ & 1 & 3 & 15 & 45 & Olası risk & $\begin{array}{l}\text { Gözetim altında } \\
\text { uygulanmalıdır. }\end{array}$ \\
\hline 28 & $\begin{array}{l}\frac{5}{0} \\
\frac{0}{0} \\
\simeq\end{array}$ & $\begin{array}{l}\text { Savurna } \\
\text { döküm } \\
\text { Makinenin } \\
\text { ani durması } \\
\text { durumunda } \\
\text { kalıbın } \\
\text { firlaması }\end{array}$ & 1 & 6 & 15 & 90 & $\begin{array}{l}\text { Önemli } \\
\text { risk }\end{array}$ & $\begin{array}{l}\text { Uzun } \\
\text { dönemde } \\
\text { iyileştirilmeli- } \\
\text { dir. }\end{array}$ & $\begin{array}{l}\text { Kalıpın yerinden cıkmasını } \\
\text { engelleyici koruyucu } \\
\text { aparatlar yapılmalıdır. }\end{array}$ & 1 & 2 & 15 & 30 & Olası risk & $\begin{array}{l}\text { Gözetim altında } \\
\text { uygulanmalıdır. }\end{array}$ \\
\hline
\end{tabular}




\begin{tabular}{|c|c|c|c|c|c|c|c|c|c|c|c|c|c|c|c|}
\hline & & & & & & & & & & & & & & & \\
\hline 29 & $\frac{\overline{0}}{0}$ & $\begin{array}{l}\text { Savurma } \\
\text { döküm } \\
\text { makinesi } \\
\text { kalıptan } \\
\text { çıartılan } \\
\text { retortun fazla } \\
\text { çekilmesi } \\
\text { sonucu } \\
\text { düşmesi }\end{array}$ & 3 & 6 & 15 & 270 & $\begin{array}{l}\text { Esasli } \\
\text { risk }\end{array}$ & $\begin{array}{l}\text { Kisa dönemde } \\
\text { iyileştirilmeli- } \\
\text { dir. }\end{array}$ & $\begin{array}{l}\text { Sehpa üzerinde aşırı çekme } \\
\text { önleyici stoper takılmalıdır. }\end{array}$ & 1 & 3 & 40 & 120 & $\begin{array}{l}\text { Önemli } \\
\text { risk }\end{array}$ & $\begin{array}{l}\text { Uzun dönemde } \\
\text { iyileştirilmelidir. }\end{array}$ \\
\hline 30 & $\frac{\pi}{0}$ & $\begin{array}{l}\text { Sicak retortun } \\
\text { soğuma } \\
\text { esnasında } \\
\text { cüruf atması } \\
\text { nedeniyle } \\
\text { göze çapak } \\
\text { kaçması } \\
\end{array}$ & 3 & 6 & 7 & 126 & $\begin{array}{l}\text { Önemli } \\
\text { risk }\end{array}$ & $\begin{array}{l}\text { Uzun } \\
\text { dönemde } \\
\text { iyileştirilmeli- } \\
\text { dir. }\end{array}$ & $\begin{array}{l}\text { Sicak malzemenin bulunduğu } \\
\text { alanlar girişi engelleyici tecrit } \\
\text { oluşturulmalıdır. Uyarı } \\
\text { levhaları asılmalıdır. }\end{array}$ & 0,5 & 6 & 15 & 45 & Olası risk & $\begin{array}{l}\text { Gözetim altında } \\
\text { uygulanmalıdır. }\end{array}$ \\
\hline 31 & $\frac{\pi}{0}$ & $\begin{array}{l}\text { Sicak retort } \\
\text { stok alanı, } \\
\text { sicak yüzeye } \\
\text { temas ve } \\
\text { yanma }\end{array}$ & 3 & 6 & 7 & 126 & $\begin{array}{l}\text { Önemli } \\
\text { risk }\end{array}$ & $\begin{array}{l}\text { Uzun } \\
\text { dönemde } \\
\text { iyileştirilmeli- } \\
\text { dir. }\end{array}$ & $\begin{array}{l}\text { Retort sehpasından retort } \\
\text { düşmesini engelleyici koruma } \\
\text { aparatı yapılmalıdır. }\end{array}$ & 0,5 & 3 & 15 & 23 & Olası risk & $\begin{array}{l}\text { Gözetim altında } \\
\text { uygulanmalıdır. }\end{array}$ \\
\hline 32 & $\frac{\pi}{0}$ & $\begin{array}{l}\text { Soğutma } \\
\text { ceketinin } \\
\text { kesimden } \\
\text { sonra düşmesi } \\
\text { sonucu } \\
\text { yaralanma } \\
\end{array}$ & 6 & 6 & 7 & 252 & $\begin{array}{l}\text { Esasl1 } \\
\text { risk }\end{array}$ & $\begin{array}{l}\text { Kısa dönemde } \\
\text { iyileştirilmeli- } \\
\text { dir. }\end{array}$ & $\begin{array}{l}\text { Ceketin düşmesni engelleyen } \\
\text { sehpa kullanılmalıdır. }\end{array}$ & 1 & 2 & 15 & 30 & Olası risk & $\begin{array}{l}\text { Gözetim altında } \\
\text { uygulanmalıdır. }\end{array}$ \\
\hline 33 & $\frac{\pi}{0}$ & $\begin{array}{l}\text { Kovanı } \\
\text { s1kışmış parça } \\
\text { kesimi } \\
\text { esnasında } \mathrm{Mg} \\
\text { metalinin } \\
\text { yanması }\end{array}$ & 1 & 6 & 7 & 42 & $\begin{array}{l}\text { Olas1 } \\
\text { risk }\end{array}$ & $\begin{array}{l}\text { Gözetim } \\
\text { altında } \\
\text { uygulanmal1- } \\
\text { dir. }\end{array}$ & $\begin{array}{l}\text { Yanmaz soğutma sıvıları ve } \\
\text { söndürücü olarak flux } \\
\text { arabaları hazır bulunmalıdır. }\end{array}$ & 1 & 3 & 7 & 21 & Olası risk & $\begin{array}{l}\text { Gözetim altında } \\
\text { uygulanmalıdır. }\end{array}$ \\
\hline 34 & $\frac{\pi}{0}$ & $\begin{array}{l}\text { Ferrosilis } \\
\text { kaynaklı } \\
\text { Kimyasallar, } \\
\text { maruziyet } \\
\text { sonucu } \\
\text { zehirlenme }\end{array}$ & 1 & 2 & 15 & 30 & $\begin{array}{l}\text { Olas1 } \\
\text { risk }\end{array}$ & $\begin{array}{l}\text { Gözetim } \\
\text { altında } \\
\text { uygulanmalı- } \\
\text { dır. }\end{array}$ & $\begin{array}{l}\text { Ferro silikat suyla temas } \\
\text { etmesi halinde zehirli gaz } \\
\text { oluşturur, çalışanlar msds } \\
\text { kayıtları asılarak } \\
\text { bilgilendirilmelidir. Uyarı } \\
\text { tabelaları asılmalıdır. }\end{array}$ & 0,2 & 6 & 15 & 18 & $\begin{array}{l}\text { Önemsiz } \\
\text { risk }\end{array}$ & $\begin{array}{l}\text { Önlem öncelikli } \\
\text { değildir. }\end{array}$ \\
\hline
\end{tabular}




\section{IV.SONUC}

Türkiye ve Avrupa'da birincil magnezyum üretim tesisinin ilk kez 2017 y1lında kurulması ve bundan önceki senelerde özellikle Türkiye'de demir çelik endüstrisi ve alüminyum endüstrisi haricinde metal konusunda sınırlı endüstriyel ve akademik bilgiye sahip olunması magnezyum tesisi için bir dezavantaj olarak kabul edilmektedir. Magnezyum üretim tesisinde diğer metal endüstri dalları ile temel proses benzerlikleri olsa da genel olarak farklı üretim aşamalarına sahiptir. Özellikle ön 1sıtıcı, kalsinasyon, peletleme ve redüksiyon ünitelerinin kurulmasında ve işletilmesinde Çin teknolojisinden yararlanılmıştır. Türk işçilerden ve Mühendislerden çoğu Çin'de magnezyum metal üretimi proses eğitimleri görmüş işle ilgili bilgi ve tecrübelerini geliştirirlerken, Çin'deki iş güvenliği uygulamalarının yetersizliği nedeniyle ekipmanların kurulum ve işletilmesi aşamalarında yaşa-tecrübe et yaklaşımı ile kendilerini yetiştirmişlerdir.

Öncelikli olarak yönetim ve işçiler arasında geri bildirim iş güvenliği kültürünün ve iş kazalarının azaltılmasında birinci etken olmuştur. İkinci etken ise ramak kala olaylarıdır. Düzenli olarak yapılan iş sağlığı ve güvenliği toplantıları işçilerin yönetime olan güvenini arttırmış ve işçilerin karşılaştıkları iş güvenliği problemlerini yönetime iletmelerini kolaylaştırarak bir güvenlik zincir halkasi oluşturulmuştur. Kazasız geçirilen aylar için üniteler arasında yeşil bayrak ödül uygulaması yapılmış ve işçilerin iş güvenliği kültürünü benimsemeleri ve katılımları sağlanmış ve içselleştirilmiştir.

Magnezyum metali üretim prosesleri aşamasında kendine özgü 34 farklı risk tespit edilmiştir. $\mathrm{Bu}$ risklerden en önemlileri magnezyum metal eriyiği sıçraması, platform üzerinde çalışan personelin zehirli gaza maruz kalması, sıcak el aletlerine vücut teması ergitme ocağı platformları üzerinde düzensiz malzeme istiflenmesi, basınçlı tüplerin forklift çatallarında kontrolsüz yatay vaziyette taşınması olarak karşımıza çıkmıştır. Yapılan geri bildirimler ve iş güvenliği kültürünün işçiler arasında benimsenmesi sonucu iki kez sıvı metal sıçraması, bir kez sıvı metale ayak teması haricinde önemli bir iş kazası yaşanmamış ve ölümcül bir iş kazası görülmemiştir.

\section{KAYNAKLAR}

[1] MME, "Esan Madencilik Sunumu" [Çevrimiçi]. Erişim Adresi: http://mme.deu.edu.tr/wpcontent/uploads/2017/08/1030_Esan.pdf. Erişim Tarihi: 01.03.2020.

[2] Kar Madencilik, "Kar Mineral Madencilik" [Çevrimiçi]. Erişim Adresi: https://www.karmadencilik.com.tr/ Erişim Tarihi: 05.01.2020.

[3] Aker, A., "Metal Sektöründe 5x5 Matris ve Fine-Kinney Yöntemi ile Risk Değerlendirmesi." Karaelmas İş Sağlığı ve Güvenliği Dergisi 4.1: 65-75.

[4] Metal Dünyası, “Türkiye'nin İlk Avrupa'nın Tek Birincil Magnezyum Üretim Tesisi” [Çevrimiçi]. Erişim Adresi: https://metaldunyasi.com.tr/tr/haberler/206/turkiyenin-ilk-avrupanin-tek-birincilmagnezyum-uretim-tesisi.html Erişim Tarihi: 12.12.2019.

[5] Y. Bayrak, "Dolomitten magnezyum üretiminde proses parametrelerinin araştırılması ve termodinamik modellenmesi," Doktora tezi, Metalurji ve Malzeme Mühendisliği Anabilim Dalı, Fen Bilimleri Enstitüsü, Yıldız Teknik Üniversitesi, İstanbul, Türkiye, 2019.

[6] Ilocis, "Chapter 16 - Occupational Health Services" [Çevrimiçi]. Erişim Adresi: http://www.ilocis.org/documents/chpt16e.htm. Erişim Tarihi: 01.10.2020.

[7] Özkiliç, Ö. (2005). İş Sağliği ve Güvenliği, Yönetim Sistemleri ve Risk Değerlendirme Metodolojileri. TISSK Yayınları, Ankara. 
[8] Gazete, R. (2012). İş Sağlığ1 Ve Güvenliği Risk Değerlendirmesi Yönetmeliği. Resmi Gazete Tarihi, (28512).

[9] B. O. Alli, Fundamental Principles of Occupational Health and Safety Second Edition, Geneva, International Labour Organization, 2008.

[10] Murphy, John F. "Kimyasal Proses Endüstrilerinde Güvenlik Hususları." Endüstriyel Kimya ve Biyoteknoloji El Kitabl. Springer, Cham, 2017. 1805-1887.

[11] S. J., Yoon, Seok, et al. "Effect of occupational health and safety management system on workrelated accident rate and differences of occupational health and safety management system awareness between managers in South Korea's construction industry." Safety and Health at Work, c. 4, s. 4, ss. 201-209, 2013.

[12] E., Hastürk, M., Uzel, "Metal döküm atölyelerinde iş sağlığı ve güvenliği koşulları," Mesleki Bilimler Dergisi, c. 6 s. 1-Düzeltme, ss. 45-58, 2017.

[13]. Kokangül, Ali, Ulviye Polat, and Cansu Dağsuyu. "A new approximation for risk assessment using the AHP and Fine Kinney methodologies." Safety science 91, 24-32. 2017.

[14] Gül, M., Güven, B., and Güneri, A. F. (2018). A new Fine-Kinney-based risk assessment framework using FAHP-FVIKOR incorporation. Journal of Loss Prevention in the Process Industries, 53, 3-16.

[15]. A., Şentürk, "Döküm Sektöründe İş Sağlığı ve Güvenliğinin Değerlendirmesi," İş Sağlığı ve Güvenliği Uzmanlık Tezi, Çalışma ve Sosyal Güvenlik Bakanlığı, İş Sağlığı ve Güvenliği Genel Müdürlüğü, Ankara, Türkiye, 2016.

[16] A. T., Yıldız, "Çimento Fabrikalarında İş Kazaları ve Meslek Hastalıklarının İş Yeri Güvenlik Kültürü ile İlişkisi: Medcem Madencilik Çimento Fabrikası Örneği," Yüksek lisans tezi, İş Sağlığı ve Güvenliği Anabilim Dalı, Lisansüstü Eğitim Enstitüsü, Tarsus Üniversitesi, Mersin, Türkiye, 2019.

[17] T., Christman, Metals Fire Protection Handbook, Twentieth Edition, Section 6, Chapter 9, ss. 152, National Fire Protection Association, 2008.

[18] L. D. Fond, Fire Department Suggested Operating Guideline, Class D Combustible Metals, Section 4, ss. 1-4, 2010.

[19] Y., Kısa, "Döküm Atölyelerindeki İş Sağllğ̣ ve Güvenliği Koşullarının Çok Ölçütlü Karar Verme Yöntemleriyle Değerlendirilmesi," İş Sağlığı ve Güvenliği Uzmanlık Tezi, Çalışma ve Sosyal Güvenlik Bakanlığı, İş Sağlığı ve Güvenliği Genel Müdürlüğü, Ankara, Türkiye, 2014.

[20] Berhan, E. (2020). Yönetim taahhüdü ve iş sağlı̆̆1 ve güvenliğinin iyileştirilmesi üzerindeki etkisi: bir demir, çelik ve metal imalat endüstrileri durumu. International Journal of Workplace Health Management.

[21] Güllüoğlu, E. N., Güllüoğlu, A. N., Türkiye' de Metal Sektöründe Meydana Gelen İş Kazalarının Analizi. International Journal Of Advances İn Engineering And Pure Sciences, 31(1), 70-82.2019.

[22] Metalstar, "Kıvaç Group" [Çevrimiçi]. Erişim Adresi: https://kivancgroup.com/isguvenligi/endustri-urunleri/metalstar/ Erişim Tarihi: 05.11.2020. 